\title{
65. EVALUATION OF QUALITY OF GEOCHEMICAL LOG DATA IN HOLE 798B ${ }^{1}$
}

\author{
James F. Bristow ${ }^{2}$ and Peter B. deMenocal ${ }^{3}$
}

\begin{abstract}
The capability of determining elemental concentrations through geochemical logging has recently been established. However, the quality of these data obtained in some environments has yet to be quantified. We assess the quality of geochemical logs compared with XRF results from a suite of core samples from Hole 798B. The resulting core/log correlations are only fair, because the tool has been adversely affected by the very high porosity of the formation. The results, however, do fall within the statistical uncertainties predicted by the processing. The recent application of a modified boron sleeve to the Ocean Drilling Program's geochemical logging tool is shown to reduce interference of borehole chlorine on the resultant chemistry.
\end{abstract}

\section{INTRODUCTION}

Geochemical logging provides continuous, in-situ measurements of the most abundant rock-forming and some trace-element concentrations. The huge database of information collected has enormous potential for a wide range of geological applications. Relative elemental variations can be used in lithological classification of both igneous and sedimentary environments (Anderson et al., 1990), as well as when determining sediment sources and paleoclimate information (deMenocal et al., this volume). Normative mineralogy determinations from the geochemistry (Herron, 1986; Harvey et al., 1990) have a variety of uses, including petrologic classification and the production of thermal conductivity profiles (Dove and Williams, 1989).

The geochemical logging tool (GLT, mark of Schlumberger Inc.) is regularly deployed in ODP logging operations to produce abundances of up to 13 elements (silicon, calcium, iron, potassium, titanium, aluminum, sulfur, gadolinium, magnesium, thorium, uranium, hydrogen, and chlorine). Geochemical logs provide a continuous measurement (every $0.152 \mathrm{~m}$ ) up the borehole and are unaffected by incomplete/preferential core recovery, one of the main problems encountered when relying on traditional, core-based studies. In addition, gathering data with this geochemical tool is comparatively easy and yields preliminary results immediately to shipboard scientists. However, the value of log-derived geochemistry for geological interpretation depends on the quality of these data. The precision and accuracy of the geochemical data obtained in many ODPenvironments is not well established. The GLT was originally designed for use by the petroleum industry in evaluating sedimentary basins. As a result, most of the work toevaluate the precision and accuracy of the tool has been conducted in "typical" reservoir sedimentary environments of sandstone-shale-limestone sequences of limited ranges of porosity. Such comparisons between core- and log-derived chemistry show the high quality of the geochemical logging data (Chapman et al., 1987; Wendlandt and Bhuyan, 1989). The quality of these results, however, are thought not to be directly applicable to ODP data, which are obtained under very different, generally poorer, logging conditions. Much of ODP logging is performed in less-lithified, high-porosity sediments having wider and less-uniform borehole diameters. These data may also be degraded by the vertical heave of the ship during logging operations. Despite the different ODP conditions, a recent study by Jarrard and Lyle (1991) of the GLT geochemistry obtained during Leg 117 found that the precision of the log-based abundances was similar to those determined by Chapman et al. (1987).

\footnotetext{
${ }^{1}$ Tamaki, K., Suyehiro, K., Allan, J., McWilliams, M., et al., 1992, Proc, ODP, Sci. Results, 127/128, Pt. 2: College Station, TX (Ocean Drilling Program).

${ }^{2}$ Borehole Research, Department of Geology, University of Leicester, Leicester LEI $7 \mathrm{RH}$, England.

${ }^{3}$ Lamont-Doherty Geological Observatory of Columbia University, Palisades, NY 10964, U.S.A.
}

This chapter evaluates the quality and reliability of the geochemical logging data obtained in Hole 798B through comparison with $\mathrm{X}$-ray fluorescence (XRF) analyses performed on core from the hole. Hole 798B was chosen for this evaluation for a number of reasons. Overall core recovery was very high and a full complement of high quality logs were obtained. One of the principal objectives of drilling at Site 798 was to reconstruct the late Neogene paleoclimatic and paleoceanographic history of the Sea of Japan. Initial shipboard interpretation of the logging data indicated a strong cyclicity in the sediments, shown to be consistent with 41 k.y. orbital obliquity variations (Shipboard Scientific Party, 1990). In addition to the core$\log$ comparisons, the XRF analyses are being used in a parallel study (deMenocal et al., this volume) to assess the use of downhole logs as a means for acquiring paleoclimatic data.

A total of 304 XRF analyses from Hole 798B are reported here. The quality of the GLT data are assessed by comparison with XRF abundances as a function of depth and by using some basic statistics and internal relationships of the individual XRF and GLT data sets. Some of the reasons for problems encountered in the processing are discussed and a method for determining the statistical uncertainty associated with the geochemical processing is presented.

\section{XRF METHODS}

Three intervals of core were selected for sampling: Interval 1, Cores $13 \mathrm{H}$ through $15 \mathrm{H}$ (113.5-142.6 mbsf); Interval 2, Cores 19X through 20X (171.6-191.3 mbsf); and Interval 3, Cores 28X through $32 \mathrm{X}$ (258.7-305.7 mbsf). Selected on the basis of good core recovery and minimal core disturbance, these intervals also contain ash layers identified in the formation microscanner (FMS) images for correlating core-log depths. Interval 1 was strip-sampled in continuous $30-\mathrm{cm}$ channels of core $\left(\sim 20 \mathrm{~cm}^{3}\right)$. The lower Intervals 2 and 3 had three discrete samples (each $4 \mathrm{~cm}^{3}$ ) taken per $30 \mathrm{~cm}$ of core, which were subsequently homogenized. Our original intention had been to stripsample all of the intervals, as this approach was thought to best approximate the moving average measurements of the logging tool data and thus would optimize the compatibility of data sets from the different measurement techniques. Unfortunately, strip-sampling in the upper interval disturbed the remaining core too much and had to be abandoned for the more traditional, but less representative, discrete sampling approach. However, the high density of this sampling is thought to provide a good representation of the generally lower-frequency lithologic variations.

The samples were oven-dried and crushed to 200-mesh powders and fused with lithium tetraborate-lithium metaborate flux. The XRF analysis was performed using a Kevex 0700/7000 energy dispersive $\mathrm{X}$-ray spectrometer at the University of Rhode Island. The data thus obtained are listed in Tables 1 through 3. 
Table 1. X-ray fluorescence data for sampled Interval 1, Cores $13 \mathrm{H}$ through 15H (113.5-142.6 mbsf).

\begin{tabular}{|c|c|c|c|c|c|c|c|c|c|c|c|c|c|c|}
\hline Core/section & $\begin{array}{l}\text { Interval } \\
(\mathrm{cm})\end{array}$ & $\begin{array}{l}\text { ODP } \\
\text { depth } \\
\text { (mbsf) }\end{array}$ & $\begin{array}{l}\text { Corrected } \\
\text { depth } \\
\text { (mbsf) }\end{array}$ & $\begin{array}{l}\mathrm{Na}_{2} \mathrm{O} \\
(w t \%)\end{array}$ & $\begin{array}{l}\mathrm{MgO} \\
(w 1 \%)\end{array}$ & $\begin{array}{l}\mathrm{Al}_{2} \mathrm{O}_{3} \\
(\mathrm{wt} \%)\end{array}$ & $\begin{array}{l}\mathrm{SiO}_{2} \\
(w t \%)\end{array}$ & $\begin{array}{l}\mathrm{P}_{2} \mathrm{O}_{5} \\
(\mathrm{wt} \%)\end{array}$ & $\begin{array}{l}\mathrm{K}_{2} \mathrm{O} \\
\text { (wt\%) }\end{array}$ & $\begin{array}{l}\mathrm{CaO} \\
(\mathrm{wt} \%)\end{array}$ & $\begin{array}{l}\mathrm{TiO}_{2} \\
\text { (wt\%) }\end{array}$ & $\begin{array}{l}\mathrm{MnO} \\
(w t \%)\end{array}$ & $\begin{array}{l}\mathrm{Fe}_{2} \mathrm{O}_{3} \\
(\mathrm{wt} \%)\end{array}$ & $\begin{array}{l}\text { Total } \\
(w t \%)\end{array}$ \\
\hline $13 \mathrm{H}-1$ & $0-30$ & 113.50 & 113.65 & 3.12 & 3.07 & 17.91 & 61.79 & 0.14 & 3.44 & 2.24 & 0.76 & 0.08 & 7.36 & 99.90 \\
\hline $13 \mathrm{H}-1$ & $60-90$ & 114.10 & 114.16 & 2.80 & 2.73 & 17.07 & 59.73 & 0.12 & 2.99 & 6.14 & 0.71 & 0.07 & 6.26 & 98.62 \\
\hline $13 \mathrm{H}-1$ & $90-119$ & 114.40 & 114.41 & 2.41 & 3.02 & 18.03 & 60.92 & 0.16 & 3.41 & 3.17 & 0.74 & 0.08 & 7.36 & 99.29 \\
\hline $13 \mathrm{H}-2$ & $0-25$ & 114.69 & 114.66 & 3.14 & 2.98 & 17.86 & 62.36 & 0.13 & 3.30 & 2.75 & 0.75 & 0.07 & 6.83 & 100.18 \\
\hline $13 \mathrm{H}-2$ & $32-61$ & 115.01 & 114.93 & 3.48 & 2.85 & 17.36 & 64.72 & 0.11 & 3.24 & 1.62 & 0.68 & 0.07 & 6.55 & 100.68 \\
\hline $13 \mathrm{H}-2$ & $61-100$ & 115.30 & 115.17 & 3.18 & 2.82 & 17.62 & 63.63 & 0.10 & 3.23 & 1.59 & 0.71 & 0.06 & 6.19 & 99.14 \\
\hline $13 \mathrm{H}-2$ & $100-125$ & 115.69 & 115.50 & 2.49 & 2.72 & 17.15 & 63.70 & 0.14 & 3.18 & 2.11 & 0.73 & 0.06 & 6.65 & 98.93 \\
\hline $13 \mathrm{H}-2$ & $125-150$ & 115.94 & 115.72 & 3.15 & 2.62 & 16.37 & 63.51 & 0.17 & 3.05 & 2.85 & 0.68 & 0.06 & 6.33 & 98.79 \\
\hline $13 \mathrm{H}-3$ & $0-30$ & 116.19 & 115.93 & 3.17 & 2.43 & 15.15 & 63.71 & 0.17 & 2.69 & 5.61 & 0.63 & 0.06 & 5.88 & 99.50 \\
\hline $13 \mathrm{H}-3$ & $30-60$ & 116.49 & 116.18 & 3.08 & 2.32 & 14.67 & 62.77 & 0.19 & 2.90 & 7.14 & 0.57 & 0.06 & 5.46 & 99.16 \\
\hline $13 \mathrm{H}-3$ & $60-90$ & 116.79 & 116.43 & 2.62 & 2.27 & 14.29 & 62.14 & 0.19 & 2.51 & 8.72 & 0.51 & 0.05 & 5.32 & 98.62 \\
\hline $13 \mathrm{H}-3$ & $90-120$ & 117.09 & 116.69 & 2.88 & 2.22 & 14.75 & 63.72 & 0.15 & 2.67 & 6.55 & 0.52 & 0.06 & 5.56 & 99.08 \\
\hline $13 \mathrm{H}-3$ & $120-150$ & 117.39 & 116.94 & 3.06 & 2.39 & 15.08 & 63.95 & 0.11 & 2.84 & 5.57 & 0.58 & 0.07 & 5.72 & 99.36 \\
\hline $13 \mathrm{H}-4$ & $0-30$ & 117.69 & 117.20 & 3.11 & 2.52 & 15.72 & 64.08 & 0.07 & 2.91 & 4.29 & 0.61 & 0.06 & 5.99 & 99.35 \\
\hline $13 \mathrm{H}-4$ & $30-60$ & 117.99 & 117.45 & 2.80 & 2.53 & 15.91 & 63.88 & 0.12 & 3.02 & 4.19 & 0.64 & 0.06 & 6.15 & 99.31 \\
\hline $13 \mathrm{H}-4$ & $60-90$ & 118.29 & 117.70 & 2.99 & 2.53 & 15.77 & 62.81 & 0.17 & 2.91 & 5.39 & 0.61 & 0.06 & 5.92 & 99.16 \\
\hline $13 \mathrm{H}-4$ & $90-120$ & 118.59 & 117.96 & 2.94 & 2.40 & 15.49 & 62.20 & 0.18 & 2.79 & 6.32 & 0.62 & 0.06 & 5.84 & 98.83 \\
\hline $13 \mathrm{H}-4$ & $120-150$ & 118.89 & 118.21 & 3.13 & 2.46 & 15.72 & 64.07 & 0.15 & 2.76 & 3.79 & 0.69 & 0.07 & 6.24 & 99.08 \\
\hline $13 \mathrm{H}-5$ & $0-30$ & 119.19 & 118.47 & 2.86 & 2.39 & 16.43 & 64.08 & 0.17 & 3.00 & 3.17 & 0.70 & 0.07 & 6.42 & 99.30 \\
\hline $13 \mathrm{H}-5$ & $30-60$ & 119.49 & 118.72 & 3.12 & 2.59 & 16.97 & 63.49 & 0.14 & 3.12 & 2.79 & 0.67 & 0.08 & 6.59 & 99.58 \\
\hline $13 \mathrm{H}-5$ & $90-120$ & 120.09 & 119.23 & 3.18 & 2.78 & 17.55 & 62.13 & 0.10 & 3.18 & 2.55 & 0.73 & 0.07 & 6.76 & 99.02 \\
\hline $13 \mathrm{H}-5$ & $120-150$ & 120.39 & 119.48 & 2.87 & 3.05 & 17.53 & 60.19 & 0.16 & 3.38 & 4.91 & 0.66 & 0.07 & 6.72 & 99.56 \\
\hline $13 \mathrm{H}-6$ & $0-30$ & 120.69 & 119.74 & 2.57 & 3.06 & 17.59 & 61.18 & 0.18 & 3.47 & 3.30 & 0.73 & 0.07 & 6.79 & 98.95 \\
\hline $13 \mathrm{H}-6$ & $30-60$ & 120.99 & 119.99 & 2.75 & 2.93 & 17.23 & 59.20 & 0.19 & 3.43 & 5.68 & 0.76 & 0.08 & 6.51 & 98.76 \\
\hline $13 \mathrm{H}-6$ & $60-90$ & 121.29 & 120.24 & 2.71 & 2.78 & 16.99 & 60.91 & 0.18 & 3.10 & 5.97 & 0.61 & 0.07 & 6.14 & 99.46 \\
\hline $13 \mathrm{H}-6$ & $90-120$ & 121.59 & 120.50 & 2.84 & 2.82 & 17.97 & 60.83 & 0.13 & 3.38 & 4.39 & 0.68 & 0.08 & 6.31 & 99.43 \\
\hline $13 \mathrm{H}-6$ & $120-150$ & 121.89 & 120.75 & 2.88 & 2.67 & 17.33 & 60.43 & 0.14 & 3.12 & 5.96 & 0.59 & 0.07 & 5.88 & 99.06 \\
\hline $13 \mathrm{H}-7$ & $0-30$ & 122.19 & 121.00 & 2.35 & 2.86 & 17.90 & 59.78 & 0.16 & 3.30 & 5.41 & 0.74 & 0.07 & 6.40 & 98.97 \\
\hline $13 \mathrm{H}-7$ & $30-60$ & 122.49 & 121.26 & 2.90 & 2.88 & 17.71 & 60.54 & 0.17 & 3.33 & 5.41 & 0.67 & 0.07 & 6.52 & 100.20 \\
\hline $13 \mathrm{H}-7$ & $60-90$ & 122.79 & 121.51 & 3.07 & 2.67 & 16.89 & 60.95 & 0.17 & 2.95 & 5.99 & 0.63 & 0.06 & 6.18 & 99.58 \\
\hline $13 \mathrm{H}-7$ & $90-120$ & 123.09 & 121.76 & 2.63 & 2.47 & 16.16 & 61.34 & 0.18 & 2.64 & 7.25 & 0.64 & 0.06 & 5.77 & 99.14 \\
\hline $13 \mathrm{H}-7$ & $120-150$ & 123.39 & 122.02 & 3.21 & 2.33 & 15.16 & 62.50 & 0.22 & 2.49 & 8.01 & 0.58 & 0.06 & 5.08 & 99.63 \\
\hline $13 \mathrm{H}-8$ & $0-30$ & 123.69 & 122.27 & 3.12 & 2.73 & 17.06 & 63.43 & 0.13 & 3.12 & 2.61 & 0.73 & 0.07 & 6.49 & 99.49 \\
\hline $13 \mathrm{H}-8$ & $30-60$ & 123.99 & 122.53 & 3.45 & 2.46 & 16.07 & 65.98 & 0.13 & 2.81 & 1.76 & 0.65 & 0.06 & 6.46 & 99.83 \\
\hline $13 \mathrm{H}-8$ & $60-90$ & 124.29 & 122.78 & 2.88 & 2.12 & 14.14 & 67.99 & 0.13 & 2.43 & 3.24 & 0.51 & 0.06 & 5.76 & 99.26 \\
\hline $13 \mathrm{H}-\mathrm{CC}$ & $0-22$ & 124.61 & 123.05 & 3.37 & 2.06 & 15.20 & 67.33 & 0.13 & 2.66 & 1.65 & 0.56 & 0.07 & 6.08 & 99.10 \\
\hline $14 \mathrm{H}-1$ & $0-30$ & 123.20 & 123.35 & 3.62 & 2.29 & 16.65 & 65.09 & 0.15 & 2.66 & 2.89 & 0.60 & 0.06 & 5.92 & 99.94 \\
\hline $14 \mathrm{H}-1$ & $30-60$ & 123.50 & 123.60 & 3.00 & 2.30 & 17.61 & 61.67 & 0.13 & 2.82 & 4.88 & 0.61 & 0.06 & 6.12 & 99.20 \\
\hline $14 \mathrm{H}-1 \mathrm{~A}$ & $60-90$ & 123.80 & 123.85 & 2.92 & 2.47 & 17.80 & 61.84 & 0.16 & 3.10 & 4.14 & 0.66 & 0.06 & 6.57 & 99.73 \\
\hline $14 \mathrm{H}-1 \mathrm{~A}$ & $90-120$ & 124.10 & 124.11 & 2.99 & 2.66 & 17.50 & 62.12 & 0.21 & 3.22 & 3.02 & 0.68 & 0.07 & 6.88 & 99.34 \\
\hline $14 \mathrm{H}-2 \mathrm{~A}$ & $0-40$ & 124.40 & 124.36 & 2.68 & 2.72 & 16.37 & 58.00 & 0.16 & 2.81 & 9.55 & 0.59 & 0.08 & 6.09 & 99.05 \\
\hline $14 \mathrm{H}-2$ & $40-90$ & 124.80 & 124.69 & 2.84 & 2.35 & 14.69 & 58.97 & 0.28 & 2.43 & 11.69 & 0.49 & 0.07 & 5.48 & 99.28 \\
\hline $14 \mathrm{H}-3 \mathrm{~A}$ & $0-30$ & 125.90 & 125.62 & 2.79 & 2.63 & 15.93 & 56.94 & 0.13 & 2.74 & 11.15 & 0.57 & 0.09 & 5.89 & 98.86 \\
\hline $14 \mathrm{H}-3$ & $30-53$ & 126.20 & 125.87 & 2.78 & 2.45 & 15.48 & 57.37 & 0.23 & 2.55 & 12.14 & 0.53 & 0.08 & 5.65 & 99.26 \\
\hline $14 \mathrm{H}-3$ & $75-108$ & 126.65 & 126.25 & 2.43 & 2.74 & 16.90 & 58.02 & 0.17 & 2.86 & 9.22 & 0.60 & 0.07 & 6.15 & 99.16 \\
\hline $14 \mathrm{H}-3$ & $116-150$ & 127.06 & 126.59 & 2.53 & 2.60 & 16.16 & 59.02 & 0.22 & 2.81 & 8.96 & 0.66 & 0.08 & 6.10 & 99.14 \\
\hline $14 \mathrm{H}-4$ & $0-30$ & 127.40 & 126.88 & 2.28 & 2.65 & 16.80 & 59.65 & 0.14 & 2.90 & 8.02 & 0.61 & 0.07 & 5.92 & 99.03 \\
\hline $14 \mathrm{H}-4$ & $30-60$ & 127.70 & 127.13 & 2.74 & 2.69 & 16.22 & 58.86 & 0.21 & 2.86 & 8.41 & 0.64 & 0.08 & 6.07 & 98.78 \\
\hline $14 \mathrm{H}-4$ & $60-90$ & 128.00 & 127.38 & 3.07 & 2.24 & 14.83 & 59.58 & 0.20 & 2.43 & 10.84 & 0.51 & 0.06 & 5.25 & 99.01 \\
\hline $14 \mathrm{H}-4$ & $90-120$ & 128.30 & 127.63 & 3.31 & 2.19 & 14.31 & 63.15 & 0.19 & 2.36 & 7.97 & 0.58 & 0.06 & 5.02 & 99.14 \\
\hline $14 \mathrm{H}-4$ & $120-150$ & 128.60 & 127.88 & 3.07 & 2.39 & 15.75 & 63.18 & 0.15 & 2.74 & 5.81 & 0.59 & 0.07 & 5.65 & 99.39 \\
\hline $14 \mathrm{H}-5 \mathrm{~A}$ & $0-30$ & 128.90 & 128.13 & 2.98 & 2.34 & 15.59 & 61.90 & 0.22 & 2.80 & 7.24 & 0.59 & 0.07 & 5.85 & 99.59 \\
\hline $14 \mathrm{H}-5$ & $30-60$ & 129.20 & 128.39 & 3.05 & 2.06 & 14.23 & 64.31 & 0.18 & 2.36 & 6.87 & 0.57 & 0.06 & 5.03 & 98.72 \\
\hline
\end{tabular}

Note: ODP depth = depth in mbsf calculated by standard ODP procedures. Corrected depth $=$ depth in mbsf as determined from terrigenous log/SGR correlation (Fig. 1).

\section{NUCLEAR LOGGING}

The quantitative downhole measurement of geochemistry relies on nuclear logging techniques (Hertzog et al., 1987). The geochemical logging tool (GLT) deployed in ODP consists of three main tool components. The natural gamma-ray spectrometry tool (NGT, mark of Schlumberger Inc.) measures the concentrations in the formation of the naturally occurring radioactive elements potassium, thorium, and uranium, using a sodium iodide scintillation detector (Lock and Hoyer, 1971). The aluminium activation clay tool (AACT, mark of Schlumberger Inc.) measures the concentration of aluminium (Al) by delayed activation using a californium source of neutrons and a scintillation detector (Scott and Smith, 1973). The gamma-ray spectrometry tool (GST, mark of Schlumberger Inc.) irradiates the formation with a neutron generator and measures the spectrum of capture-induced gamma rays (Hertzog, 1979). The spectrum is in- verted at each depth level $(0.1524 \mathrm{~m})$ to give the relative yields of the elements $\mathrm{Si}, \mathrm{Ca}, \mathrm{Fe}, \mathrm{H}, \mathrm{Cl}, \mathrm{S}, \mathrm{Ti}, \mathrm{K}$, and $\mathrm{Gd}$ in the formation. These data are combined with the $\mathrm{Al}$ and $\mathrm{K}$ (both wt\%) from the AACT and NGT in a Schlumberger algorithm that converts the GST-derived elemental yields into dry weight percent oxides. The GLT and the standard processing techniques employed for the data from Leg 128 are described in more detail by Bristow et al. (this volume). Some nonstandard processing procedures applied to the geochemical data from Hole 798B during processing for this particular study are described below.

\section{PROBLEMS AND PROCESSING OF HOLE 798B}

One of the main reasons for problems encountered when geochemically logging Hole 798B was the very high porosity of the soft sediments. Opal content in the three sampled intervals averages 
Table 1 (continued).

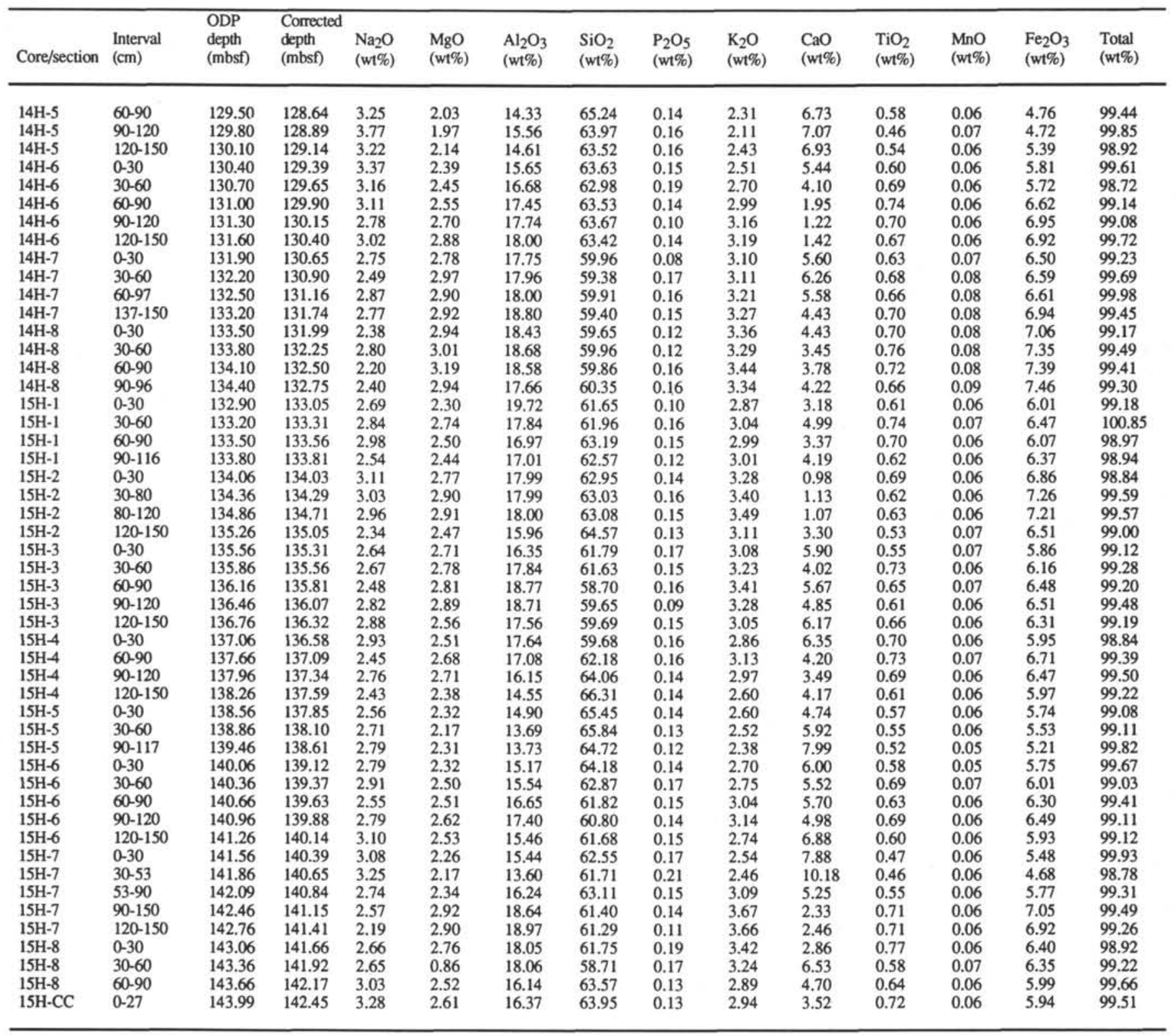

$16.6 \%$ by weight, which contributes strongly to the high porosity. Porosity values average $75 \%, 72 \%$ and $78 \%$ in the sampled Intervals 1,2 , and 3 , respectively. The porosity curve used for processing the geochemical data was derived from the lithodensity tool and correlates well with shipboard core porosity measurements (Shipboard Scientific Party, 1990).

High porosity causes most of the capture gamma-rays detected by the GST to be from $\mathrm{Cl}$ and $\mathrm{H}$ in the formation and borehole, not from the matrix-forming elements. Typically in Hole 798B, 70\% to $75 \%$ of the detected spectrum was derived from these two elements, both of which have high neutron capture cross sections. The statistics of the matrix-derived captured gamma rays thus are poor. Two complete runs of the GST were done in this hole and initial correlation of the matrix-derived elemental yields from the two runs was poor.

In a recent study by Jarrard and Lyle (1991), they noted that a strong correlation existed between $\mathrm{Cl}$ and the other elemental yields and that these correlations were similar to the proprietary Schlumberger repartitioning coefficients for $\mathrm{Cl}$. Jarrard and Lyle
(1991) resolved that nearly all of the small-scale Cl-yield character was a partitioning problem and "fixed" the $\mathrm{Cl}$ curve as straight regression lines with depth, repartitioning the small-scale character to the other yields. In this study, again, a fairly strong correlation was seen between the $\mathrm{Cl}$ regressions against the other elemental yields and the Schlumberger repartitioning coefficients for $\mathrm{Cl}$.

In Hole 798B, a strong correlation exists between the $\mathrm{Cl}$-yield from the GST and the lithodensity-derived porosity curve, with the correlation, $R=0.85$, for both GST runs. The $\mathrm{Cl}$ yield exhibited the 3- to 5-m cyclic nature of the porosity in the formation. Such a good correlation on a relatively fine scale between the $\mathrm{Cl}$-yield and formation porosity has not been described in ODP logging before and may be the result of the recent addition of the boron sleeve to the GST (ODP Leg 126), which was designed to reduce gamma-ray counts from the borehole fluid (primarily $\mathrm{Cl}$ and $\mathrm{H}$ ).

However, the $\mathrm{Cl}$-yield exhibited noise on the finer scale $(<3 \mathrm{~m})$; thus, to improve the other elemental yields, it was "fixed" to the porosity $\log$, which was devoid of this noise. This was performed by calculating a 
Table 2. X-ray fluorescence data for sampled Interval 2, Cores 19X through 20X (171.6-191.0 mbsf).

\begin{tabular}{|c|c|c|c|c|c|c|c|c|c|c|c|c|c|c|}
\hline Core/section & $\begin{array}{l}\text { Interval } \\
(\mathrm{cm})\end{array}$ & $\begin{array}{l}\text { ODP } \\
\text { depth } \\
\text { (mbsf) }\end{array}$ & $\begin{array}{l}\text { Corrected } \\
\text { depth } \\
\text { (mbsf) }\end{array}$ & $\begin{array}{l}\mathrm{Na}_{2} \mathrm{O} \\
(\mathrm{wt} \%)\end{array}$ & $\begin{array}{l}\mathrm{MgO} \\
(\mathrm{wt} \%)\end{array}$ & $\begin{array}{l}\mathrm{Al}_{2} \mathrm{O}_{3} \\
(\mathrm{wt} \%)\end{array}$ & $\begin{array}{l}\mathrm{SiO}_{2} \\
\text { (wt\%) }\end{array}$ & $\begin{array}{l}\mathrm{P}_{2} \mathrm{O}_{5} \\
\text { (wt\%) }\end{array}$ & $\begin{array}{l}\mathrm{K}_{2} \mathrm{O} \\
(\mathrm{wt} \%)\end{array}$ & $\begin{array}{l}\mathrm{CaO} \\
(\mathrm{wt} \%)\end{array}$ & $\begin{array}{l}\mathrm{TiO}_{2} \\
\text { (wt\%) }\end{array}$ & $\begin{array}{l}\mathrm{MnO} \\
(\mathrm{wt} \%)\end{array}$ & $\begin{array}{l}\mathrm{Fe}_{2} \mathrm{O}_{3} \\
\text { (wt } \%)\end{array}$ & Total \\
\hline $19 X-1$ & $5-26$ & 171.76 & 171.99 & 3.34 & 2.47 & 15.34 & 62.34 & 0.13 & 2.48 & 8.63 & 0.48 & 0.06 & 5.08 & 100.35 \\
\hline $19 X-1$ & $35-56$ & 172.05 & 172.23 & 3.06 & 2.47 & 15.34 & 60.50 & 0.20 & 2.66 & 8.30 & 0.66 & 0.06 & 5.64 & 98.89 \\
\hline $19 X-1$ & $65-84$ & 172.35 & 172.47 & 2.56 & 1.81 & 15.21 & 63.04 & 0.17 & 2.18 & 10.06 & 0.58 & 0.05 & 4.87 & 100.53 \\
\hline $19 X-1$ & $95-111$ & 172.63 & 172.72 & 2.95 & 1.79 & 11.14 & 67.08 & 0.16 & 1.92 & 9.43 & 0.44 & 0.05 & 4.46 & 99.43 \\
\hline $19 X-1$ & $125-146$ & 172.96 & 172.96 & 3.30 & 1.85 & 11.43 & 67.52 & 0.14 & 2.04 & 7.79 & 0.44 & 0.05 & 4.57 & 99.12 \\
\hline $19 X-2$ & $4-26$ & 173.21 & 173.20 & 3.08 & 1.74 & 12.57 & 69.29 & 0.10 & 2.16 & 5.51 & 0.53 & 0.05 & 4.70 & 99.73 \\
\hline $19 X-2$ & $35-59$ & 173.51 & 173.46 & 3.21 & 1.77 & 13.36 & 65.23 & 0.19 & 2.28 & 7.23 & 0.54 & 0.06 & 4.87 & 98.74 \\
\hline $19 X-2$ & $70-91$ & 173.87 & 173.72 & 3.15 & 1.85 & 15.56 & 63.81 & 0.18 & 2.39 & 6.92 & 0.53 & 0.07 & 5.19 & 99.66 \\
\hline $19 X-2$ & $100-121$ & 174.16 & 173.97 & 2.91 & 1.91 & 15.29 & 64.23 & 0.18 & 2.56 & 5.91 & 0.55 & 0.07 & 5.27 & 98.87 \\
\hline $19 \times-2 / 3$ & $130 / 1$ & 174.46 & 174.21 & 3.11 & 1.95 & 15.59 & 66.48 & 0.12 & 2.44 & 3.51 & 0.62 & 0.07 & 5.26 & 99.14 \\
\hline $19 X-3$ & $10-30$ & 174.76 & 174.45 & 3.57 & 2.02 & 16.20 & 66.91 & 0.14 & 2.61 & 1.73 & 0.65 & 0.07 & 5.50 & 99.41 \\
\hline $19 X-3$ & $39-59$ & 175.05 & 174.68 & 3.48 & 2.30 & 17.46 & 64.93 & 0.15 & 3.13 & 1.53 & 0.68 & 0.07 & 6.16 & 99.88 \\
\hline $19 X-3$ & $70-91$ & 175.37 & 174.93 & 3.08 & 2.08 & 15.26 & 66.05 & 0.18 & 2.79 & 3.65 & 0.58 & 0.06 & 5.25 & 98.98 \\
\hline $19 X-3$ & $99-121$ & 175.66 & 175.17 & 3.35 & 2.38 & 15.96 & 63.39 & 0.25 & 2.81 & 6.02 & 0.48 & 0.06 & 4.63 & 99.32 \\
\hline $19 X-3 / 4$ & $140 / 1$ & 176.01 & 175.42 & 2.88 & 2.74 & 17.44 & 63.15 & 0.15 & 3.23 & 2.74 & 0.60 & 0.06 & 5.88 & 98.87 \\
\hline $19 X-4$ & $10-30$ & 176.26 & 175.66 & 3.25 & 2.56 & 17.39 & 64.31 & 0.14 & 3.16 & 1.48 & 0.68 & 0.07 & 5.88 & 98.93 \\
\hline $19 \times-4$ & $38-61$ & 176.55 & 175.89 & 2.71 & 2.08 & 16.96 & 65.44 & 0.15 & 3.39 & 1.57 & 0.67 & 0.07 & 5.84 & 98.89 \\
\hline $19 X-4$ & $70-90$ & 176.86 & 176.14 & 2.99 & 1.30 & 14.98 & 68.78 & 0.11 & 3.26 & 3.41 & 0.46 & 0.07 & 4.47 & 99.82 \\
\hline $19 \times-4$ & $100-121$ & 177.16 & 176.38 & 3.59 & 1.76 & 12.72 & 69.35 & 0.09 & 2.50 & 3.79 & 0.49 & 0.06 & 4.93 & 99.28 \\
\hline $19 X-4 / 5$ & $140 / 1$ & 177.51 & 176.62 & 3.88 & 1.53 & 12.23 & 70.28 & 0.08 & 2.58 & 3.60 & 0.47 & 0.07 & 4.61 & 99.34 \\
\hline $19 X-5$ & $10-30$ & 177.76 & 176.87 & 3.52 & 1.47 & 12.53 & 69.54 & 0.13 & 3.47 & 3.74 & 0.52 & 0.08 & 4.12 & 99.12 \\
\hline $19 X-5$ & $38-59$ & 178.04 & 177.09 & 3.10 & 1.75 & 11.99 & 70.17 & 0.11 & 2.29 & 5.05 & 0.45 & 0.06 & 4.30 & 99.28 \\
\hline $19 X-5$ & $69-93$ & 178.36 & 177.36 & 3.30 & 1.82 & 14.00 & 66.86 & 0.10 & 2.90 & 4.42 & 0.54 & 0.08 & 4.83 & 98.85 \\
\hline $19 X-5$ & $100-121$ & 178.66 & 177.59 & 3.18 & 2.00 & 14.51 & 67.10 & 0.06 & 2.76 & 3.70 & 0.61 & 0.06 & 5.20 & 99.18 \\
\hline $19 X-5 / 6$ & $130 / 6$ & 178.99 & 177.86 & 3.44 & 2.14 & 16.21 & 65.47 & 0.15 & 3.11 & 3.76 & 0.69 & 0.08 & 5.61 & 100.65 \\
\hline $19 X-6$ & $15-36$ & 179.32 & 178.11 & 3.06 & 2.59 & 16.67 & 63.30 & 0.17 & 2.99 & 3.75 & 0.74 & 0.07 & 6.30 & 99.63 \\
\hline $19 \times-6$ & $45-67$ & 179.62 & 178.36 & 2.92 & 3.09 & 17.07 & 62.11 & 0.13 & 3.33 & 3.51 & 0.72 & 0.07 & 6.61 & 99.56 \\
\hline $19 \times-6$ & $78-104$ & 179.97 & 178.65 & 2.72 & 3.06 & 17.01 & 60.63 & 0.17 & 3.25 & 5.11 & 0.75 & 0.07 & 6.24 & 99.01 \\
\hline $19 \times-6$ & $117-136$ & 180.32 & 178.93 & 2.54 & 2.90 & 17.03 & 60.43 & 0.13 & 3.22 & 5.36 & 0.71 & 0.08 & 6.59 & 98.99 \\
\hline $19 \mathrm{X}-6 / \mathrm{CC}$ & $146 / 18$ & 180.63 & 179.16 & 2.59 & 2.83 & 16.31 & 59.66 & 0.20 & 3.12 & 7.22 & 0.68 & 0.08 & 6.38 & 99.07 \\
\hline $20 \mathrm{X}-1$ & $4-26$ & 181.41 & 179.63 & 2.91 & 2.99 & 18.12 & 63.13 & 0.13 & 3.50 & 1.32 & 0.72 & 0.06 & 7.10 & 99.99 \\
\hline $20 \mathrm{X}-1$ & $34-57$ & 181.62 & 179.89 & 2.43 & 2.95 & 18.17 & 62.67 & 0.14 & 3.62 & 1.42 & 0.72 & 0.07 & 6.78 & 98.98 \\
\hline $20 \mathrm{X}-1 / 2$ & $65 / 9$ & 181.84 & 180.15 & 2.67 & 2.91 & 18.43 & 62.61 & 0.15 & 3.66 & 1.52 & 0.83 & 0.07 & 7.00 & 99.86 \\
\hline
\end{tabular}

Note: ODP depth = depth in mbsf calculated by standard ODP procedures. Corrected depth $=$ depth in mbsf as determined from terrigenous log/SGR correlation (Fig. 1).

$\mathrm{Cl}$ curve from a second-order regression of the porosity log. The difference between the calculated and the original $\mathrm{Cl}$ curves was redistributed to the other elemental yields, which improved the correlation of the matrix-derived yields from the two runs. These were then laterally averaged to improve the elemental yield uncertainties further.

The yields of S and Ca produced at the initial inversion of the spectral data were found to be very noisy and to contain many negative values, which induced instability into the other elemental yields. This is caused partly by a shortcoming in the type of mathematical inversion (weighted least-squares) used on the spectral data; however, this point is beyond the scope of this study to evaluate fully. Available core data at the time of processing suggested that $\mathrm{S}$ and in most parts $\mathrm{Ca}$ were well below the concentration levels necessary for detection by the tool (Chapman et al., 1987). The inversion of the spectral data was repeated without these elements, which improved the overall stability of the other elemental yields. Subsequent XRF analysis of core data, presented here, shows that $\mathrm{Ca}$ does reach significant concentrations in the upper two sampled intervals. An approximate $\mathrm{Ca}$ curve thus was generated in these intervals when "fixing" the GST K-yield to the much more reliable K curve that was derived from the NGT. The difference between the GST K curve and the NGT K curve is redistributed to the other matrix-forming elemental yields. The standard redistribution coefficient for $\mathrm{Ca}$ was used, despite an input Ca-yield of zero and an approximate $\mathrm{Ca}$ curve generated by the redistribution at this stage in the upper portion of the hole. Although this is not an established procedure, the $\mathrm{Ca}$ curve is shown to have a fair correlation with the XRF analyses (Figs. 2, 3, and 4).

\section{CORE-LOG DEPTH CORRELATION}

The most common and largest source of error when comparing log data with core data is depth mismatch. This can be caused by a variety of reasons. As core recovery is rarely $100 \%$, it is difficult to determine where a section of core, in an incomplete barrel, was located in the formation. ODP's standard policy is to hang the core from the top of the barrel, which assumes material was lost from the base, which is not always the case. Preferential core recovery, in which the recovery is lithologically dependent, can introduce large bias into core-derived data sets. Fortunately in Hole 798B, the lithological variation is relatively limited in terms of the contrast in sediment physical properties, excepting some sparse, large calcareous and dolomitic layers and nodules.

At Hole 798B, considerable core disturbance came from sediment degassing, which occurred both while the core was being brought to the surface and while it was on deck. Some cored material from the bottom of the core barrel was forced out during the journey to the surface. Voids found within core sections were assumed to have been caused by degassing and were skipped in the sampling procedure, thus assuming the core material to be contiguous in nature. Tables 1 , 2 , and 3 show two log depths, the official ODP depth and a corrected depth used for core/log comparison for this study. The official ODP depth takes the total distance from the top of the core barrel to the sample, inclusive of voids. It was clear from preliminary comparisons with $\log$ data that this depth scale was inadequate, with some core intervals missing and some core "stretched" by degassing.

For this study, core-log depth correlation was performed based on a comparison of the total gamma-ray curve (SGR) from the NGT with a proxy "terrigenous percent" curve, derived from opal analyses of the core data. The proxy terrigenous percent curve calculated as a residual of the opal content ( $100 \%$ - weight \% opal), although the true terrigenous percent needs to include carbonate and organic carbon, it was sufficient for the purposes of this correlation. The SGR represents the total formation radioactivity reflecting the concentration of the naturally occurring elements of $\mathrm{K}, \mathrm{U}$, and $\mathrm{Th}$, which are 
Table 2 (continued),

\begin{tabular}{|c|c|c|c|c|c|c|c|c|c|c|c|c|c|c|}
\hline Core/section & $\begin{array}{l}\text { Interval } \\
(\mathrm{cm})\end{array}$ & $\begin{array}{l}\text { ODP } \\
\text { depth } \\
\text { (mbsf) }\end{array}$ & $\begin{array}{l}\text { Corrected } \\
\text { depth } \\
\text { (mbsf) }\end{array}$ & $\begin{array}{l}\mathrm{Na}_{2} \mathrm{O} \\
\text { (wt\%) }\end{array}$ & $\begin{array}{l}\mathrm{MgO} \\
\text { (wt\%) }\end{array}$ & $\begin{array}{l}\mathrm{Al}_{2} \mathrm{O}_{3} \\
\text { (wt\%) }\end{array}$ & $\begin{array}{l}\mathrm{SiO}_{2} \\
\text { (wt\%) }\end{array}$ & $\begin{array}{l}\mathrm{P}_{2} \mathrm{O}_{5} \\
\text { (wt\%) }\end{array}$ & $\begin{array}{l}\mathrm{K}_{2} \mathrm{O} \\
\text { (wt\%) }\end{array}$ & $\begin{array}{l}\mathrm{CaO} \\
(w t \%)\end{array}$ & $\begin{array}{l}\mathrm{TiO}_{2} \\
\text { (wt\%) }\end{array}$ & $\begin{array}{l}\mathrm{MnO} \\
(\mathrm{wt} \%)\end{array}$ & $\begin{array}{l}\mathrm{Fe}_{2} \mathrm{O}_{3} \\
(\mathrm{wt} \%)\end{array}$ & Total \\
\hline $20 X-2$ & $18-40$ & 182.05 & 180.41 & 2.98 & 2.87 & 17.65 & 61.62 & 0.12 & 3.42 & 2.73 & 0.78 & 0.07 & 6.75 & 98.99 \\
\hline $20 X-2$ & $48-69$ & 182.27 & 180.65 & 2.75 & 2.64 & 16.96 & 62.99 & 0.19 & 3.16 & 2.87 & 0.78 & 0.07 & 6.31 & 98.72 \\
\hline $20 \times-2$ & $81-105$ & 182.48 & 180.93 & 2.75 & 2.45 & 15.40 & 66.02 & 0.17 & 2.91 & 2.42 & 0.67 & 0.06 & 6.09 & 98.94 \\
\hline $20 X-2$ & $123-144$ & 182.70 & 181.26 & 2.89 & 2.37 & 15.78 & 64.88 & 0.10 & 2.96 & 3.50 & 0.67 & 0.07 & 6.24 & 99.47 \\
\hline $20 X-3$ & $3-30$ & 182.91 & 181.54 & 3.08 & 2.40 & 17.28 & 62.42 & 0.13 & 3.72 & 3.23 & 0.68 & 0.10 & 6.14 & 99.17 \\
\hline $20 X-3$ & $39-52$ & 183.13 & 181.80 & 2.73 & 2.44 & 14.98 & 60.99 & 0.23 & 2.77 & 8.59 & 0.65 & 0.08 & 5.40 & 98.86 \\
\hline $20 X-3 / 4$ & $70 / 10$ & 183.34 & 182.03 & 2.85 & 2.21 & 13.97 & 61.95 & 0.22 & 2.49 & 8.90 & 0.61 & 0.09 & 5.49 & 98.78 \\
\hline $20 \times-4$ & $83-110$ & 183.56 & 183.01 & 3.53 & 1.97 & 14.18 & 66.46 & 0.17 & 2.35 & 4.58 & 0.61 & 0.07 & 5.24 & 99.17 \\
\hline $20 \times-4$ & $119-149$ & 183.77 & 183.31 & 4.05 & 1.68 & 16.79 & 64.63 & 0.13 & 3.65 & 2.26 & 0.62 & 0.13 & 5.31 & 99.27 \\
\hline $20 X-5$ & $9-36$ & 183.99 & 183.63 & 3.23 & 2.04 & 14.16 & 68.34 & 0.09 & 2.45 & 2.31 & 0.56 & 0.06 & 5.68 & 98.92 \\
\hline $20 \times-5$ & $45-67$ & 184.20 & 183.89 & 3.24 & 1.98 & 13.48 & 70.23 & 0.09 & 2.30 & 1.77 & 0.61 & 0.05 & 5.24 & 98.99 \\
\hline $20 X-5$ & $76-107$ & 184.42 & 184.19 & 3.00 & 1.87 & 12.74 & 71.78 & 0.12 & 2.19 & 1.70 & 0.58 & 0.05 & 5.16 & 99.19 \\
\hline $20 X-5$ & $96-130$ & 184.63 & 184.35 & 3.35 & 1.78 & 11.54 & 73.31 & 0.09 & 2.18 & 2.00 & 0.45 & 0.05 & 4.65 & 99.40 \\
\hline $20 X-5 / 6$ & $139 / 10$ & 184.85 & 184.65 & 3.08 & 1.64 & 11.03 & 72.98 & 0.10 & 2.08 & 3.37 & 0.47 & 0.05 & 4.47 & 99.26 \\
\hline $20 \times-6$ & $50-70$ & 185.06 & 184.89 & 3.85 & 1.49 & 13.52 & 67.76 & 0.17 & 3.12 & 4.00 & 0.46 & 0.09 & 4.46 & 98.92 \\
\hline $20 x-6$ & $61-41$ & 185.28 & 185.15 & 3.37 & 1.57 & 11.76 & 69.77 & 0.14 & 2.24 & 5.33 & 0.43 & 0.06 & 4.38 & 99.05 \\
\hline $20 \times-6$ & $98-149$ & 185.49 & 185.66 & 3.09 & 1.97 & 12.87 & 70.47 & 0.06 & 2.20 & 2.90 & 0.57 & 0.05 & 5.08 & 99.27 \\
\hline $20 x-7$ & $7-76$ & 185.71 & 186.21 & 3.28 & 2.18 & 13.42 & 68.73 & 0.12 & 2.30 & 3.16 & 0.61 & 0.05 & 5.54 & 99.38 \\
\hline $20 x-7$ & $86-111$ & 185.92 & 186.68 & 2.95 & 2.12 & 13.69 & 68.65 & 0.13 & 2.35 & 2.95 & 0.64 & 0.05 & 5.28 & 98.81 \\
\hline $20 X-7 / 8$ & $119 / 8-33$ & 186.14 & 187.03 & 3.29 & 2.26 & 14.26 & 68.46 & 0.11 & 2.41 & 2.15 & 0.65 & 0.05 & 5.37 & 99.00 \\
\hline $20 \times-8 / 9$ & $39 / 13$ & 186.35 & 187.36 & 2.83 & 2.29 & 15.09 & 66.94 & 0.16 & 2.64 & 2.36 & 0.65 & 0.06 & 5.85 & 98.87 \\
\hline $20 \times-9$ & $20-42$ & 186.57 & 187.59 & 2.75 & 2.31 & 15.21 & 66.99 & 0.14 & 2.58 & 2.27 & 0.67 & 0.06 & 5.84 & 98.81 \\
\hline $20 X-9$ & $52-73$ & 186.78 & 187.85 & 3.05 & 2.35 & 15.75 & 66.07 & 0.08 & 2.83 & 2.11 & 0.63 & 0.06 & 6.21 & 99.15 \\
\hline $20 \times-9$ & $82-101$ & 187.00 & 188.08 & 3.30 & 2.29 & 15.30 & 66.16 & 0.12 & 2.75 & 2.44 & 0.62 & 0.06 & 6.08 & 99.13 \\
\hline $20 \mathrm{X}-\mathrm{CC}$ & $9-30$ & 187.21 & 188.31 & 2.49 & 2.77 & 16.32 & 61.13 & 0.16 & 3.10 & 5.77 & 0.63 & 0.08 & 6.57 & 99.02 \\
\hline
\end{tabular}

primarily terrestrially derived. The correlations for the three intervals used for the geochemical comparison are shown in Figure 1.

The core data were first corrected for gas expansion and then correlated to the SGR log by linear compression/expansion of each core. In each of the cored intervals, ash layers are visible in the core and on the microresistivity images of the borehole wall that were produced by the FMS. The depths of the ashes in the cores have been fixed to the corresponding log depths from the FMS images, thus permitting highly accurate $(0.152 \mathrm{~m})$ core-log correlation at these points. The log depths themselves are subject to uncertainties caused by cable stretch and the heave of the ship during logging operations. The logging depths from the different tool strings have been accurately correlated with a Schlumberger auto-correlative program employed on the gamma-ray data from the NGT, which is run on all of the tool strings.

An additional problem when comparing core-log geochemistry is the volume disparity between the core and log measurements. XRF is conducted on a small, discrete volume of rock $\left(\sim 10 \mathrm{~cm}^{3}\right)$, while the GLT analyses use a volume of approximately $1 \mathrm{~m}^{3}$ (Hertzog et al., 1989). This disparity can lead to substantial differences, especially in very heterogeneous formations. The dense sampling procedure employed in this study attempts to minimize this problem, but does not eradicate it.

\section{XRF AND GLT POPULATIONS}

An initial appraisal of the quality of the geochemical logging data can be made by looking at some statistics and internal relationships of the log- and core-derived data sets. This avoids such problems as depth mismatching and sampling frequency and gives an indication of the integrity of a comparison of the two data populations as a function of depth.

Figure 2 shows the average weight percentages of core- and logderived elemental oxides from the three sampled intervals, with error bars indicating \pm 1 sigma. These data are listed in Table 4 , where both data sets have been normalized. The overall agreement is good, although the variance of the log data is significantly greater. In all intervals, $\mathrm{SiO}_{2}$ is underestimated in the log data by $3 \%$ to $5 \%$.
Kleiner-Hartigan diagrams (Kleiner and Hartigan, 1981) can be used to illustrate the inter-element relationships within the XRF and GLT data sets; these are shown for the three sampled intervals in Figure 3 (see also Table 5). The XRF data show the expected strong negative correlation of $\mathrm{SiO}_{2}$ with the other oxides. Core data show that opal is strongly correlated with $\mathrm{XRF} \mathrm{SiO}_{2}$ (deMenocal et al., this volume), which in turn is negatively correlated with the other oxides contained in minerals primarily of terrestrial origin.

One can see from Table 5 that the GLT-derived oxides have much poorer correlations, and their relationships as shown in Figure 3 are much different from those of the XRF data and are not consistent between the three intervals. The internal relationships seem poorest in Interval 2, where $\mathrm{SiO}_{2}$ has a positive correlation with $\mathrm{TiO}_{2}$ and $\mathrm{K}_{2} \mathrm{O}$. The data for the entire openhole logged interval of Hole 798B (Fig. 3, Table 4) show a much greater consistency with correlations observed in the XRF data and of the expected inter-elemental relationships. This may be a reflection of the higher quality of the log-derived geochemical data in the less porous, lower half of the hole.

\section{COMPARISON OF XRF AND GLT DATA AS A FUNCTION OF DEPTH}

The core XRF and log-derived geochemistry for the three cored intervals is compared as a function of depth in Figures 4 through 6 . The core data have been depth correlated using the "terrigenous"/ gamma-ray correlation as shown in Figure 1. The correlation coefficients are displayed in Table 6; as the log data have a higher sampling frequency, the XRF analyses have been paired off with the nearest equivalent $\log$ depth. These correlation coefficients thus are very highly dependent on accurate core/log depth correlation. Evidence from the high resolution variation of some oxides can be seen in the $\log$ and core data (Figs. 4 through 6) that some minor depth offsets still remain. These small depth differences are not consistent among all of the oxides and have not been altered; the qualitative nature of these plots allows for small discrepancies to be taken into consideration.

The relative core/log variation for Interval 1 is fair for $\mathrm{SiO}_{2}$ and $\mathrm{Fe}_{2} \mathrm{O}_{3}$. It is generally poor for the remaining elements, as can be seen from the low, and in the case of $\mathrm{CaO}$ and $\mathrm{Al}_{2} \mathrm{O}_{3}$ the zero correlation 
Table 3. X-ray fluorescence data for sampled Interval 3, Cores 28X through 32X (258.7-305.7 mbsf).

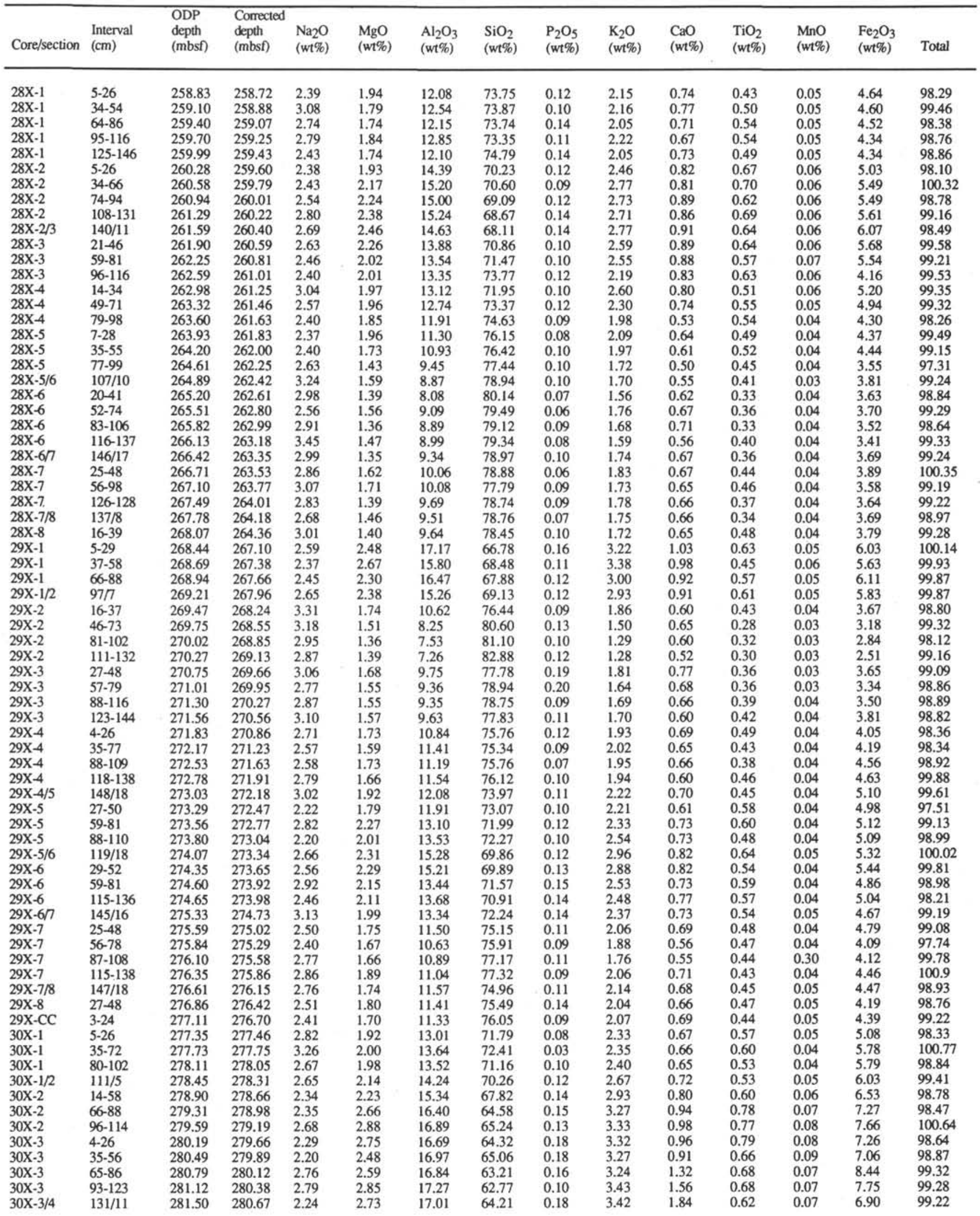

Note: ODP depth = depth in mbsf calculated by standard ODP procedures. Corrected depth $=$ depth in mbsf as determined from terrigenous log/SGR correlation (Fig. 1). 
Table 3 (continued).

\begin{tabular}{|c|c|c|c|c|c|c|c|c|c|c|c|c|c|c|}
\hline Core/section & $\begin{array}{l}\text { Interval } \\
(\mathrm{cm})\end{array}$ & $\begin{array}{l}\text { ODP } \\
\text { depth } \\
\text { (mbsf) }\end{array}$ & $\begin{array}{l}\text { Corrected } \\
\text { depth } \\
\text { (mbsf) }\end{array}$ & $\begin{array}{l}\mathrm{Na}_{2} \mathrm{O} \\
(\mathrm{w} t \%)\end{array}$ & $\begin{array}{l}\mathrm{MgO} \\
\text { (wt\%) }\end{array}$ & $\begin{array}{l}\mathrm{Al}_{2} \mathrm{O}_{3} \\
\text { (wt\%) }\end{array}$ & $\begin{array}{l}\mathrm{SiO}_{2} \\
\text { (wt\%) }\end{array}$ & $\begin{array}{l}\mathrm{P}_{2} \mathrm{O}_{5} \\
(\mathrm{w} \%)\end{array}$ & $\begin{array}{l}\mathrm{K}_{2} \mathrm{O} \\
\text { (wt\%) }\end{array}$ & $\begin{array}{l}\mathrm{CaO} \\
(\mathrm{w} t \%)\end{array}$ & $\begin{array}{l}\mathrm{TiO}_{2} \\
\text { (wt\%) }\end{array}$ & $\begin{array}{l}\mathrm{MnO} \\
\text { (wt\%) }\end{array}$ & $\begin{array}{l}\mathrm{Fe}_{2} \mathrm{O}_{3} \\
\text { (wt\%) }\end{array}$ & Total \\
\hline $30 \times-4$ & $18-43$ & 281.84 & 280.93 & 2.63 & 1.94 & 16.21 & 67.49 & 0.14 & 3.82 & 1.40 & 0.47 & 0.08 & 5.32 & 99.49 \\
\hline $30 \times-4$ & $70-89$ & 282.33 & 281.31 & 2.65 & 2.44 & 15.65 & 68.05 & 0.12 & 2.96 & 0.96 & 0.61 & 0.07 & 6.03 & 99.54 \\
\hline $30 \times-4$ & $97-120$ & 282.62 & 281.54 & 2.19 & 2.28 & 15.23 & 67.37 & 0.12 & 2.82 & 0.94 & 0.68 & 0.06 & 6.35 & 98.04 \\
\hline $30 \times-4 / 5$ & $129 / 17$ & 282.93 & 281.78 & 2.12 & 2.17 & 14.86 & 68.08 & 0.12 & 2.68 & 0.68 & 0.61 & 0.05 & 7.29 & 98.66 \\
\hline $30 X-5$ & $26-45$ & 283.22 & 282.00 & 2.15 & 2.50 & 17.63 & 63.75 & 0.12 & 3.09 & 0.64 & 0.78 & 0.06 & 7.42 & 98.16 \\
\hline $30 X-5$ & $57-77$ & 283.54 & 282.25 & 2.10 & 2.70 & 17.27 & 63.81 & 0.17 & 3.24 & 0.78 & 0.81 & 0.07 & 6.95 & 97.89 \\
\hline $30 X-5$ & $87-109$ & 283.85 & 282.49 & 2.39 & 3.02 & 17.35 & 63.39 & 0.15 & 3.41 & 1.06 & 0.86 & 0.10 & 7.05 & 98.78 \\
\hline $30 \times-5 / 6$ & $125 / 2$ & 284.25 & 282.80 & 2.16 & 2.87 & 17.18 & 63.81 & 0.18 & 3.31 & 1.06 & 0.76 & 0.08 & 8.02 & 99.42 \\
\hline $30 \times-6$ & $9-29$ & 284.56 & 283.04 & 2.30 & 2.60 & 16.59 & 64.95 & 0.15 & 3.14 & 0.99 & 0.70 & 0.06 & 7.55 & 99.03 \\
\hline $30 \times-6$ & $38-59$ & 284.85 & 283.26 & 2.93 & 2.39 & 15.96 & 67.40 & 0.10 & 2.79 & 0.78 & 0.71 & 0.06 & 6.26 & 99.39 \\
\hline $30 \times-6$ & $69-93$ & 285.17 & 283.51 & 2.67 & 2.01 & 15.24 & 69.75 & 0.15 & 2.66 & 0.87 & 0.57 & 0.05 & 6.39 & 100.36 \\
\hline $30 X-6$ & $100-121$ & 285.47 & 283.74 & 2.62 & 2.18 & 15.16 & 71.77 & 0.09 & 2.89 & 0.88 & 0.49 & 0.04 & 5.04 & 101.16 \\
\hline $30 \mathrm{X}-\mathrm{CC}$ & $1-19$ & 285.82 & 284.01 & 2.66 & 2.18 & 15.57 & 66.79 & 0.11 & 3.00 & 0.82 & 0.66 & 0.06 & 7.16 & 99.00 \\
\hline $31 \mathrm{X}-1$ & $3-25$ & 286.51 & 288.14 & 3.16 & 1.54 & 10.51 & 76.62 & 0.11 & 1.99 & 0.64 & 0.45 & 0.06 & 3.61 & 98.69 \\
\hline $31 X-1$ & $35-56$ & 286.80 & 288.40 & 3.09 & 1.26 & 10.76 & 77.03 & 0.11 & 2.02 & 0.64 & 0.39 & 0.06 & 3.29 & 98.64 \\
\hline $31 \mathrm{X}-1 / 2$ & $65 / 16$ & 287.08 & 288.65 & 2.78 & 1.22 & 10.43 & 75.64 & 0.12 & 2.09 & 0.73 & 0.35 & 0.06 & 3.73 & 97.15 \\
\hline $31 \times-2$ & $25-46$ & 287.36 & 288.90 & 2.91 & 1.10 & 10.83 & 78.58 & 0.07 & 2.09 & 0.86 & 0.36 & 0.06 & 3.51 & 100.37 \\
\hline $31 X-2$ & 55.76 & 287.64 & 289.16 & 3.57 & 1.16 & 10.79 & 76.76 & 0.11 & 2.14 & 1.09 & 0.33 & 0.06 & 3.29 & 99.30 \\
\hline $31 X-2$ & $85-106$ & 287.92 & 289.41 & 3.41 & 1.19 & 11.10 & 76.43 & 0.11 & 2.25 & 0.85 & 0.40 & 0.06 & 3.36 & 99.17 \\
\hline $31 X-2$ & $115-136$ & 288.19 & 289.65 & 3.07 & 1.32 & 10.69 & 76.68 & 0.09 & 2.06 & 0.66 & 0.44 & 0.05 & 3.60 & 98.66 \\
\hline $31 \mathrm{X}-2 / 3$ & $145 / 15$ & 288.47 & 289.91 & 2.89 & 1.41 & 11.11 & 77.38 & 0.11 & 2.03 & 0.60 & 0.41 & 0.05 & 3.42 & 99.42 \\
\hline $31 X-3$ & $94-113$ & 289.38 & 290.73 & 2.99 & 1.31 & 11.03 & 75.93 & 0.11 & 2.11 & 0.68 & 0.41 & 0.06 & 3.48 & 98.10 \\
\hline $31 X-3$ & $124-146$ & 289.67 & 290.99 & 3.37 & 1.12 & 11.08 & 77.50 & 0.06 & 2.22 & 0.76 & 0.38 & 0.06 & 3.40 & 99.95 \\
\hline $31 X-4$ & $7-28$ & 289.98 & 291.27 & 3.20 & 1.17 & 11.34 & 76.51 & 0.11 & 2.39 & 0.72 & 0.35 & 0.06 & 3.30 & 99.15 \\
\hline $31 \times-4$ & $39-63$ & 290.28 & 291.54 & 2.85 & 0.93 & 11.24 & 77.82 & 0.07 & 2.24 & 0.85 & 0.31 & 0.07 & 3.39 & 99.76 \\
\hline $31 \times-4$ & $77-94$ & 290.61 & 291.84 & 3.66 & 0.96 & 12.26 & 74.68 & 0.06 & 2.50 & 1.03 & 0.39 & 0.09 & 3.29 & 98.92 \\
\hline $31 \times-4$ & $117-140$ & 291.00 & 292.19 & 3.20 & 1.14 & 11.21 & 76.45 & 0.11 & 2.19 & 0.87 & 0.33 & 0.07 & 3.81 & 99.37 \\
\hline $31 \times-4 / 5$ & $149 / 19$ & 291.29 & 292.46 & 2.72 & 1.40 & 10.55 & 76.72 & 0.06 & 1.97 & 0.56 & 0.44 & 0.05 & 4.81 & 99.28 \\
\hline $31 X-5$ & $33-51$ & 291.59 & 292.73 & 3.35 & 1.42 & 10.56 & 76.23 & 0.03 & 2.06 & 0.57 & 0.46 & 0.05 & 4.26 & 98.98 \\
\hline $31 X-5$ & $101-124$ & 292.25 & 293.32 & 3.14 & 1.25 & 11.67 & 73.90 & 0.05 & 2.59 & 0.63 & 0.46 & 0.07 & 3.85 & 97.60 \\
\hline $31 X-5 / 6$ & $134 / 10$ & 292.57 & 293.61 & 2.80 & 1.48 & 11.62 & 75.47 & 0.07 & 2.27 & 0.60 & 0.52 & 0.05 & 4.15 & 99.03 \\
\hline $31 \times-6$ & $19-40$ & 292.87 & 293.88 & 2.60 & 1.62 & 12.26 & 73.85 & 0.08 & 2.41 & 0.62 & 0.45 & 0.05 & 4.99 & 98.91 \\
\hline $31 X-6$ & $55-76$ & 293.20 & 294.18 & 3.27 & 1.45 & 13.02 & 73.51 & 0.09 & 2.93 & 0.75 & 0.41 & 0.08 & 4.37 & 99.87 \\
\hline $31 \times-6$ & $85-106$ & 293.48 & 294.44 & 2.90 & 1.58 & 11.99 & 73.43 & 0.10 & 2.33 & 0.61 & 0.50 & 0.06 & 4.41 & 97.91 \\
\hline $31 X-6 / 7$ & $115 / 4$ & 293.75 & 294.68 & 2.82 & 1.69 & 11.77 & 74.39 & 0.08 & 2.14 & 0.65 & 0.50 & 0.04 & 4.82 & 98.91 \\
\hline $31 \times-7$ & $13-68$ & 294.19 & 295.08 & 2.50 & 1.72 & 13.40 & 73.67 & 0.14 & 2.34 & 0.74 & 0.55 & 0.04 & 5.53 & 100.63 \\
\hline $31 X-7$ & $77-96$ & 294.61 & 295.46 & 2.74 & 1.90 & 13.37 & 72.42 & 0.11 & 2.33 & 0.73 & 0.49 & 0.05 & 4.79 & 98.91 \\
\hline $31 X-7$ & $106-127$ & 294.89 & 295.71 & 3.32 & 1.35 & 12.82 & 73.87 & 0.10 & 2.64 & 0.71 & 0.37 & 0.09 & 4.44 & 99.71 \\
\hline $31 X-7 / 8$ & $136 / 7$ & 295.16 & 295.95 & 2.52 & 1.76 & 12.64 & 73.51 & 0.12 & 2.21 & 0.70 & 0.44 & 0.04 & 4.86 & 98.79 \\
\hline $31 X-8$ & $13-37$ & 295.43 & 296.20 & 2.92 & 1.51 & 12.17 & 74.14 & 0.09 & 2.15 & 0.72 & 0.53 & 0.05 & 4.63 & 98.92 \\
\hline $31 \mathrm{X}-8 / \mathrm{CC}$ & $46 / 10$ & 295.72 & 296.46 & 3.22 & 1.30 & 9.52 & 77.31 & 0.13 & 1.92 & 0.68 & 0.40 & 0.06 & 3.74 & 98.28 \\
\hline $31 \mathrm{X}-\mathrm{CC}$ & $19-30$ & 295.94 & 296.66 & 3.79 & 1.02 & 11.77 & 74.07 & 0.14 & 2.67 & 0.99 & 0.47 & 0.10 & 3.93 & 98.95 \\
\hline $32 \mathrm{X}-1$ & $4-26$ & 296.15 & 296.67 & 3.10 & 1.47 & 11.03 & 75.42 & 0.08 & 1.82 & 0.53 & 0.47 & 0.04 & 4.23 & 98.18 \\
\hline $32 X-1$ & $35-59$ & 296.47 & 296.91 & 2.73 & 1.51 & 10.56 & 77.57 & 0.07 & 1.84 & 0.59 & 0.38 & 0.04 & 3.95 & 99.24 \\
\hline $32 X-1$ & $65-86$ & 296.75 & 297.12 & 2.33 & 1.36 & 10.89 & 76.73 & 0.10 & 1.85 & 0.53 & 0.48 & 0.04 & 3.81 & 98.11 \\
\hline $32 \mathrm{X}-1$ & $93-117$ & 297.05 & 297.34 & 2.83 & 1.42 & 10.84 & 75.94 & 0.11 & 1.79 & 0.58 & 0.49 & 0.04 & 4.19 & 98.24 \\
\hline $32 X-1$ & $126-146$ & 297.36 & 297.57 & 2.93 & 1.52 & 11.71 & 75.34 & 0.08 & 1.98 & 0.59 & 0.43 & 0.04 & 4.22 & 98.84 \\
\hline $32 X-2$ & $6-26$ & 297.66 & 297.79 & 2.58 & 1.56 & 11.93 & 74.39 & 0.08 & 2.06 & 0.62 & 0.46 & 0.04 & 4.31 & 98.02 \\
\hline $32 X-2$ & $35-56$ & 297.95 & 298.01 & 3.24 & 1.43 & 12.66 & 73.96 & 0.09 & 2.31 & 0.71 & 0.48 & 0.05 & 4.37 & 99.30 \\
\hline $32 X-2$ & $65-82$ & 298.23 & 298.21 & 2.67 & 2.05 & 12.57 & 72.30 & 0.18 & 2.36 & 0.74 & 0.58 & 0.05 & 5.10 & 98.61 \\
\hline $32 X-2$ & $93-116$ & 298.54 & 298.45 & 2.56 & 1.33 & 12.12 & 77.04 & 0.08 & 2.04 & 0.65 & 0.37 & 0.04 & 4.26 & 100.49 \\
\hline $32 X-3$ & $3-25$ & 298.87 & 298.69 & 2.70 & 1.63 & 12.33 & 75.71 & 0.05 & 1.94 & 0.58 & 0.46 & 0.05 & 4.30 & 99.75 \\
\hline $32 \mathrm{X}-3$ & $32-70$ & 299.24 & 298.97 & 2.45 & 1.38 & 11.04 & 76.70 & 0.07 & 1.92 & 0.53 & 0.47 & 0.05 & 4.25 & 98.85 \\
\hline $32 X-3$ & $82-100$ & 299.64 & 299.26 & 2.63 & 1.38 & 9.46 & 78.66 & 0.06 & 1.69 & 0.50 & 0.34 & 0.04 & 4.11 & 98.86 \\
\hline $32 X-3$ & $109-131$ & 299.93 & 299.48 & 2.79 & 1.63 & 10.13 & 77.14 & 0.02 & 1.88 & 0.56 & 0.42 & 0.05 & 4.29 & 98.90 \\
\hline $32 X-3 / 4$ & $137 / 41$ & 300.37 & 299.80 & 2.82 & 1.37 & 9.77 & 78.26 & 0.06 & 1.72 & 0.54 & 0.32 & 0.05 & 3.81 & 98.72 \\
\hline $32 \times-4$ & $49-68$ & 300.81 & 300.13 & 3.34 & 1.38 & 9.96 & 77.68 & 0.06 & 1.91 & 0.54 & 0.38 & 0.06 & 3.72 & 99.03 \\
\hline $32 X-4 / 5$ & $81 / 9$ & 301.42 & 300.59 & 3.08 & 1.34 & 9.40 & 78.98 & 0.08 & 1.78 & 0.48 & 0.42 & 0.04 & 3.58 & 99.18 \\
\hline $32 \times-5$ & $17-39$ & 302.01 & 301.02 & 2.79 & 1.22 & 10.77 & 77.86 & 0.06 & 2.31 & 0.63 & 0.34 & 0.05 & 3.49 & 99.52 \\
\hline $32 X-5$ & $48-68$ & 302.31 & 301.25 & 2.96 & 1.77 & 14.20 & 70.96 & 0.06 & 2.52 & 0.53 & 0.57 & 0.05 & 5.39 & 99.02 \\
\hline $32 \times-6$ & $20-86$ & 302.97 & 301.74 & 2.94 & 2.01 & 15.60 & 67.55 & 0.13 & 2.84 & 0.72 & 0.61 & 0.06 & 6.21 & 98.68 \\
\hline $32 X-6$ & $99-126$ & 303.49 & 302.12 & 2.40 & 2.07 & 15.64 & 68.45 & 0.16 & 2.73 & 0.67 & 0.60 & 0.05 & 6.04 & 98.81 \\
\hline $32 \times-6 / 7$ & $125 / 50$ & 303.96 & 302.47 & 2.95 & 2.31 & 16.99 & 67.01 & 0.11 & 2.86 & 0.74 & 0.69 & 0.06 & 6.45 & 100.17 \\
\hline $32 X-8$ & $10-31$ & 304.44 & 302.83 & 2.38 & 2.43 & 14.87 & 62.47 & 0.23 & 2.70 & 7.44 & 0.54 & 0.08 & 5.48 & 98.62 \\
\hline $32 X-8$ & $39-60$ & 304.73 & 303.04 & 1.80 & 2.65 & 14.34 & 57.30 & 0.35 & 2.51 & 12.97 & 0.38 & 0.08 & 5.33 & 97.70 \\
\hline $32 X-8$ & $69-92$ & 305.04 & 303.27 & 2.13 & 2.49 & 14.81 & 59.81 & 0.31 & 2.62 & 9.27 & 0.47 & 0.08 & 5.48 & 97.48 \\
\hline $32 \mathrm{X}-8 / \mathrm{CC}$ & $100 / 4$ & 305.34 & 303.50 & 2.60 & 2.10 & 15.24 & 68.52 & 0.09 & 2.59 & 0.82 & 0.65 & 0.06 & 5.95 & 98.62 \\
\hline $32 \mathrm{X}-\mathrm{CC}$ & $11-26$ & 305.58 & 303.68 & 3.02 & 1.37 & 9.94 & 78.25 & 0.07 & 1.77 & 0.50 & 0.38 & 0.04 & 3.69 & 99.03 \\
\hline
\end{tabular}



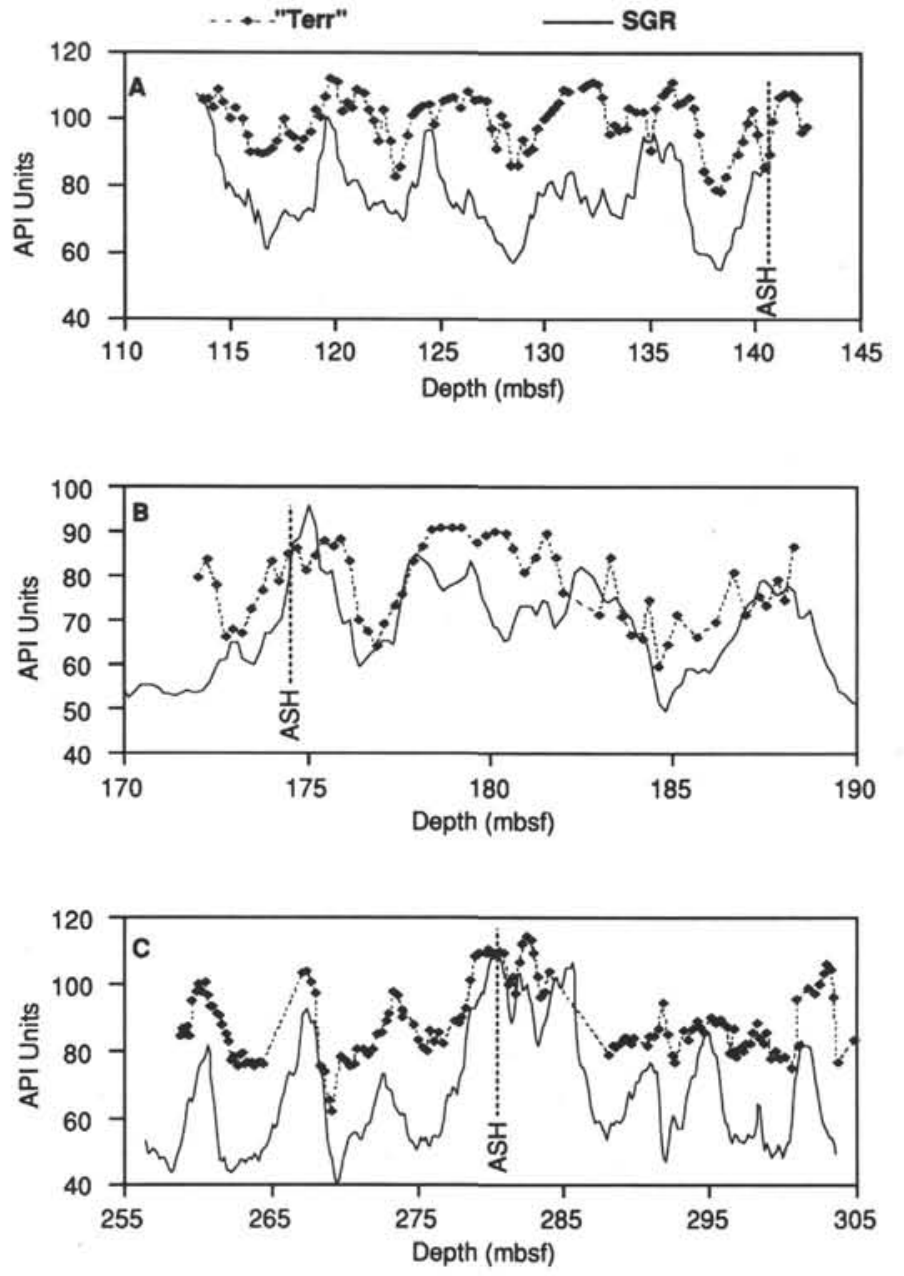

Figure 1. Correlation of "terrigenous" percent (calculated as 100-opal) with total gamma-ray (SGR) curve from the NGT for the three sampled intervals. This correlation was performed by a linear compression/expansion of the sediment from each of the core barrels to best fit the SGR curve. The ash layers marked were seen by eye in the cores and were identified in microresistivity images from the FMS. Interval 1, Cores $13 \mathrm{H}$ through $15 \mathrm{H}$, ash depth: log-140.4 mbsf, Core 15H-7 $(55 \mathrm{~cm})$. Interval 2, Cores 19X through 20X, ash depth: log-174.7 mbsf, Core 19X-3 (82 cm). Interval 3, Cores $28 \mathrm{X}$ through $32 \mathrm{X}$, ash depth: log-280.5, Core $30 \mathrm{X}-4(40-45 \mathrm{~cm})$.

coefficients (Table 5). The poor correlation of $\mathrm{Al}_{2} \mathrm{O} 3$ and $\mathrm{TiO}_{2}$ is related partly to the high frequency, noisy nature of these two logs in particular, with $\mathrm{TiO}_{2}$ additionally overestimated in the log data by a factor of 1.9. The largest discrepancy in $\mathrm{SiO}_{2}, \mathrm{Fe}_{2} \mathrm{O}_{3}$, and $\mathrm{CaO}$ occurring at 137 mbsf corresponds with a high peak in the normalization factor (Fig. 7) indicative of poor count statistics at this level.

The correlation coefficients for Interval 2 are slightly better, with $\mathrm{SiO}_{2}$, $\mathrm{CaO}$, and $\mathrm{FeO}$ showing fair agreement. $\mathrm{Al}_{2} \mathrm{O}_{3}$ again shows the poorest agreement, with the log data showing a much greater degree of variance.

Interval 3 is characterized by a much greater degree of variance in the XRF data, which the logs reflect well. $\mathrm{SiO}_{2}, \mathrm{Fe}_{2} \mathrm{O}_{3}$ and $\mathrm{K}_{2} \mathrm{O}$ all have a correlation coefficient of approximately 0.5 , which is reasonable considering that this lower sampled interval was affected most by the degassing core disturbance. It is apparent from the discontinuous nature of the XRF points that core material is missing. This is the only interval sampled in which some significant variance was seen in the $\mathrm{XRF} \mathrm{TiO}_{2}$ values, the character of which is reflected in the log responses, even though the magnitude of the variance in the logs is much greater and could be ameliorated with a greater degree of smoothing. $\mathrm{Al}_{2} \mathrm{O}_{3}$ is overestimated by a factor of 1.45 in this interval. Correlation while low, is higher than in the upper sampled intervals.

Over the three sampled intervals the $\mathrm{Fe}_{2} \mathrm{O}_{3}, \mathrm{SiO}_{2}$, and $\mathrm{K}_{2} \mathrm{O}$ have the best overall core/log correlations. The correlation of $\mathrm{Fe}_{2} \mathrm{O}_{3}$ with core data relative to correlation with the other GST elements seems improved from the study of Jarrard and Lyle (1991) of Leg 117 data. This indicates a possible improvement brought about by the recent addition of the boron sleeve to the GST. An Fe correction had to be used for the log data before the addition of the sleeve to the tool.

\section{SOURCE OF ERRORS}

Although the arithmetic means of the core and log data sets are similar, it has been shown that the correlation of the variance and the inter-element relationships of the log data are only fair to poor in comparison with XRF data. Two main sources of error exist: the first is the disparity in the data populations caused by factors such as incorrect depth assignment, ship's heave, and measurement volume differences, already discussed, and the second is the errors associated with the geochemical processing techniques.

Grau et al. (1990) considered statistical uncertainties associated with elemental determination by thermal neutron capture measurements. Their approach involved simulating the gamma-ray spectrum produced by a given rock composition and then subjecting the resulting spectrum to varying amounts of statistical noise to simulate environmental effects. By repeating this procedure 2000 times and processing each of the spectra in the same way as they would real data, they were able to quantify the uncertainties associated with the technique.

Table 4. Summary statistics for core XRF and geochemical log-derived oxides for the three sampled intervals.

\begin{tabular}{|c|c|c|c|c|c|c|}
\hline \multirow{2}{*}{$\begin{array}{l}\text { Interval } \\
\text { and type }\end{array}$} & \multicolumn{6}{|c|}{ Major Oxides } \\
\hline & $\mathrm{SiO}_{2}$ & $\mathrm{CaO}$ & $\mathrm{Fe}_{2} \mathrm{O}_{3}$ & $\mathrm{TiO}_{2}$ & $\mathrm{~K}_{2} \mathrm{O}$ & $\mathrm{Al}_{2} \mathrm{O}_{3}$ \\
\hline \multicolumn{7}{|l|}{ 1-XRF } \\
\hline Mean & 66.326 & 5.453 & 6.612 & 0.681 & 3.166 & 17.716 \\
\hline Standard deviation & 2.280 & 2.608 & 0.651 & 0.081 & 0.359 & 1.486 \\
\hline Variance & 5.200 & 6.803 & 0.423 & 0.006 & 0.129 & 2.209 \\
\hline \multicolumn{6}{|l|}{$1-\log$} & $\mathrm{N}=183$ \\
\hline Mean & 61.963 & 6.611 & 8.594 & 1.278 & 3.210 & 18.344 \\
\hline Standard deviation & 6.398 & 5.514 & 2.309 & 0.507 & 0.636 & 3.325 \\
\hline Variance & 40.938 & 30.408 & 5.331 & 0.257 & 0.405 & 11.057 \\
\hline \multicolumn{7}{|l|}{ 2-XRF } \\
\hline \multicolumn{7}{|l|}{$\mathrm{N}=58$} \\
\hline Mean & 70.166 & 4.380 & 5.868 & 0.646 & 2.961 & 15.979 \\
\hline Standard deviation & 3.457 & 2.456 & 0.824 & 0.107 & 0.518 & 2.140 \\
\hline Variance & 11.952 & 6.034 & 0.679 & 0.041 & 0.269 & 4.580 \\
\hline \multicolumn{7}{|l|}{$\begin{array}{l}2-\log \\
\mathrm{N}=109\end{array}$} \\
\hline Mean & 64.546 & 6.711 & 6.988 & 1.151 & 3.038 & 17.566 \\
\hline Standard deviation & 4.309 & 5.351 & 1.294 & 0.501 & 0.504 & 2.843 \\
\hline Variance & 18.570 & 28.631 & 1.675 & 0.251 & 0.254 & 8.084 \\
\hline \multicolumn{7}{|l|}{ 3. XRF } \\
\hline \multicolumn{7}{|l|}{$\mathrm{N}=143$} \\
\hline Mean & 78.420 & $\ldots$ & 5.133 & 0.536 & 2.487 & 13.424 \\
\hline Standard deviation & 4.687 & $\ldots$ & 1.348 & 0.134 & 0.567 & 2.764 \\
\hline Variance & 21.969 & $\cdots$ & 1.817 & 0.018 & 0.322 & 7.638 \\
\hline \multicolumn{3}{|l|}{$\mathrm{N}=297$} & & & & \\
\hline Mean & 72.716 & $\ldots$ & 3.572 & 0.739 & 3.314 & 19.660 \\
\hline Standard deviation & 3.675 & $\ldots$ & 1.675 & 0.407 & 0.777 & 3.568 \\
\hline Variance & 13.503 & $\ldots$ & 2.806 & 0.165 & 0.604 & 12.732 \\
\hline
\end{tabular}



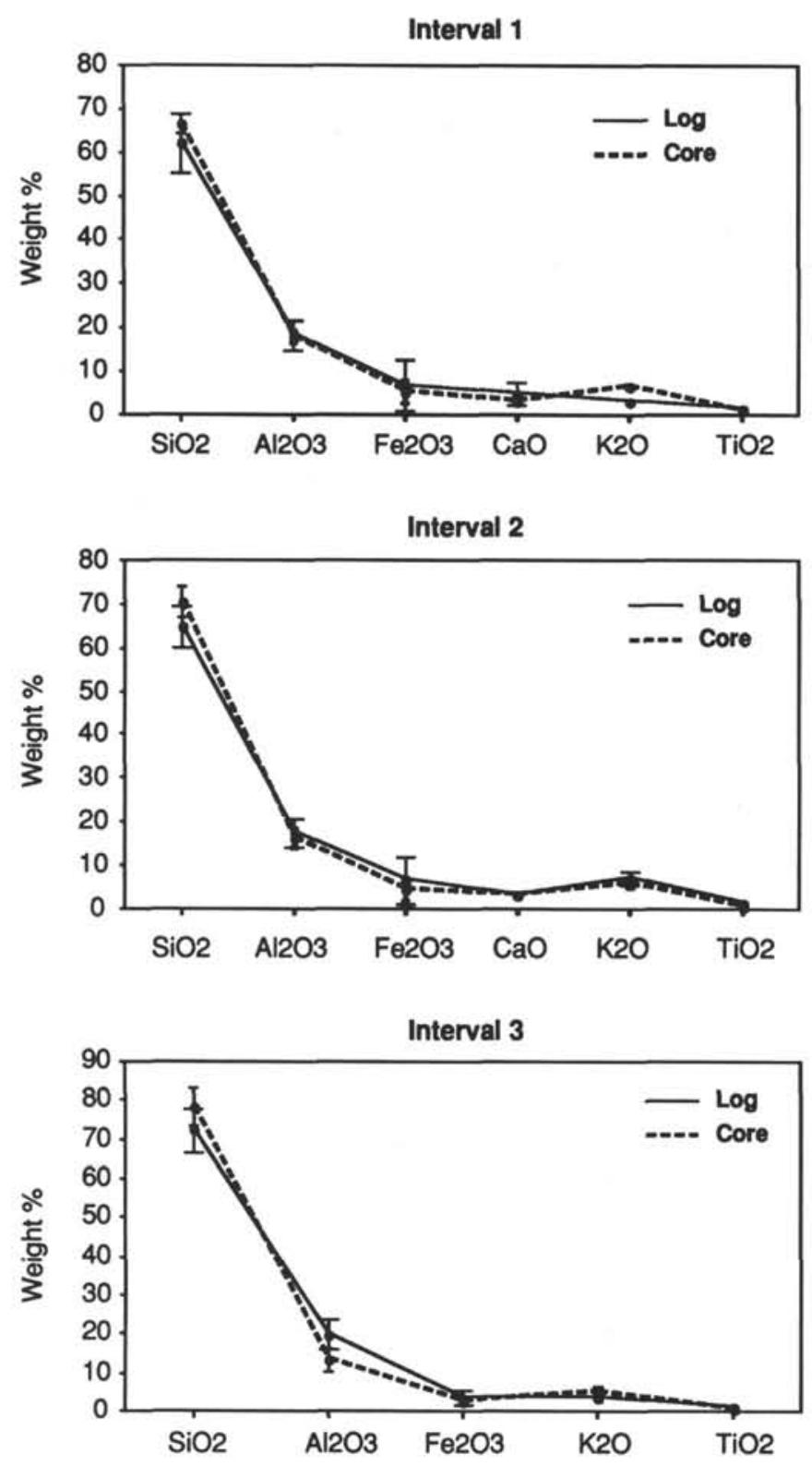

Figure 2. Arithmetic means of oxide data for the three sampled intervals derived from core XRF and geochemical log-derived measurements. Both log and XRF data sets have been normalized for the elements shown. Error bars indicate 1 standard deviation ( \pm 1 sigma) and are shown only where they are visibly discernible (see also Table 4). Wide "T" bars are log data, narrow " $T$ " bars indicate XRF data.

Two examples of the statistical error range of GST elements, based on the equations of Grau et al. (1990), are shown in Figure 8. The statistical errors are high in the measured elements, principally because of the high porosity environment that resulted in only a small proportion of the captured gamma rays to come from the rock-forming matrix. With the incorporation of this calculated statistical error, the log data are seen to encompass almost all of the XRF measurements. This is the case with most of the GSTderived elements for the three compared intervals. The calculated error is strongly related to the normalization factor, which is determined at each depth level in the closure model to convert the relative elemental yields into weight percent oxides (Hertzog et al., 1989). As the proportion of the gamma-ray contribution from the
Table 5. Product moment correlation matrices produced by R-mode hierarchical cluster analysis for the core XRF and geochemical log-derived oxides for the three sampled intervals.

\begin{tabular}{|c|c|c|c|c|c|}
\hline \multirow{2}{*}{$\begin{array}{l}\text { Interval } \\
\text { and type }\end{array}$} & \multicolumn{5}{|c|}{ Major Oxides } \\
\hline & $\mathrm{SiO}_{2}$ & $\mathrm{Fe}_{2} \mathrm{O}_{3}$ & $\mathrm{TiO}_{2}$ & $\mathrm{~K}_{2} \mathrm{O}$ & $\mathrm{Al}_{2} \mathrm{O}_{3}$ \\
\hline \multicolumn{6}{|l|}{ 1: $\log$} \\
\hline $\mathrm{SiO}_{2}$ & 1.0000 & -0.6022 & -0.2459 & -0.0353 & -0.1896 \\
\hline $\mathrm{Fe}_{2} \mathrm{O}_{3}$ & - & 1.0000 & 0.6084 & 0.0428 & -0.5498 \\
\hline $\mathrm{TiO}_{2}$ & - & - & 1.0000 & -0.1371 & -0.4617 \\
\hline $\mathrm{K}_{2} \mathrm{O}$ & - & - & - & 1.0000 & 0.1237 \\
\hline \multirow{2}{*}{$\mathrm{Al}_{2} \mathrm{O}_{3}$} & - & - & - & - & 1.0000 \\
\hline & & - & - & - & - \\
\hline \multicolumn{6}{|l|}{ 2: Log } \\
\hline $\mathrm{SiO}_{2}$ & 1.0000 & -0.5878 & 0.0786 & 0.3362 & -0.1265 \\
\hline $\mathrm{Fe}_{2} \mathrm{O}_{3}$ & - & 1.0000 & 0.0782 & -0.3332 & -0.4112 \\
\hline $\mathrm{TiO}_{2}$ & - & - & 1.0000 & 0.2347 & -0.2253 \\
\hline $\mathrm{K}_{2} \mathrm{O}$ & - & & - & 1.0000 & 0.2134 \\
\hline $\mathrm{Al}_{2} \mathrm{O}_{3}$ & - & - & - & - & 1.0000 \\
\hline \multicolumn{6}{|l|}{ 3: $\log$} \\
\hline $\mathrm{SiO}_{2}$ & 1.0000 & -0.3179 & 0.0279 & -0.1833 & -0.5938 \\
\hline $\mathrm{Fe}_{2} \mathrm{O}_{3}$ & - & 1.0000 & 0.5509 & 0.3526 & -0.3085 \\
\hline $\mathrm{TiO}_{2}$ & - & - & 1.0000 & 0.3446 & -0.2349 \\
\hline $\mathrm{K}_{2} \mathrm{O}$ & - & - & - & 1.0000 & 0.0433 \\
\hline $\mathrm{Al}_{2} \mathrm{O}_{3}$ & - & - & - & - & 1.0000 \\
\hline \multicolumn{6}{|l|}{ 1: XRF } \\
\hline $\mathrm{SiO}_{2}$ & 1.0000 & -0.2271 & -0.1532 & -0.3221 & -0.4423 \\
\hline $\mathrm{Fe}_{2} \mathrm{O}_{3}$ & - & 1.0000 & 0.7388 & 0.8796 & 0.8091 \\
\hline $\mathrm{TiO}_{2}$ & - & & 1.0000 & 0.7266 & 0.7024 \\
\hline $\mathrm{K}_{2} \mathrm{O}$ & - & - & - & 1.0000 & 0.8546 \\
\hline $\mathrm{Al}_{2} \mathrm{O}_{3}$ & - & - & - & - & 1.0000 \\
\hline \multicolumn{6}{|l|}{ 2: XRF } \\
\hline $\mathrm{SiO}_{2}$ & 1.0000 & -0.6638 & -0.6136 & -0.5686 & -0.7780 \\
\hline $\mathrm{Fe}_{2} \mathrm{O}_{3}$ & - & 1.0000 & 0.8974 & 0.6252 & 0.8321 \\
\hline $\mathrm{TiO}_{2}$ & - & - & 1.0000 & 0.6134 & 0.8069 \\
\hline $\mathrm{K}_{2} \mathrm{O}$ & - & - & - & 1.0000 & 0.7953 \\
\hline $\mathrm{Al}_{2} \mathrm{O}_{3}$ & - & - & - & - & 1.0000 \\
\hline \multicolumn{6}{|l|}{ 3: XRF } \\
\hline $\mathrm{SiO}_{2}$ & 1.0000 & -0.9349 & -0.8832 & -0.9293 & -0.9770 \\
\hline $\mathrm{Fe}_{2} \mathrm{O}_{3}$ & - & 1.0000 & 0.8825 & 0.7924 & 0.8944 \\
\hline $\mathrm{TiO}_{2}$ & - & - & 1.0000 & 0.7355 & 0.8485 \\
\hline $\mathrm{K}_{2} \mathrm{O}$ & - & - & - & 1.0000 & 0.9468 \\
\hline $\mathrm{Al}_{2} \mathrm{O}_{3}$ & - & - & - & - & 1.0000 \\
\hline \multicolumn{6}{|c|}{ Whole openhole logged interval } \\
\hline $\mathrm{SiO}_{2}$ & 1.0000 & -0.3512 & -0.1079 & -0.1931 & -0.5245 \\
\hline $\mathrm{Fe}_{2} \mathrm{O}_{3}$ & - & 1.0000 & 0.4839 & -0.0176 & -0.4250 \\
\hline $\mathrm{TiO}_{2}$ & - & - & 1.0000 & 0.01480 & -0.2224 \\
\hline $\mathrm{K}_{2} \mathrm{O}$ & - & - & - & 1.0000 & 0.2715 \\
\hline $\mathrm{Al}_{2} \mathrm{O}_{3}$ & - & - & - & - & 1.0000 \\
\hline
\end{tabular}

matrix-forming elements decreases, so the normalization factor increases. This occurs where there is an increase in borehole diameter or in the porosity of the formation. Therefore, under conditions of relatively uniform hole diameter, the normalization factor is related to the porosity of the formation. This exponential relationship is well illustrated in Figure 9. Many of the larger deviations in core/log chemistry (Figs. 4 through 6) are associated with peaks in the nor-

Table 6. Correlation coefficients for core XRF and geochemical log-derived oxides.

\begin{tabular}{ccccccr}
\hline Interval & $\mathrm{SiO}_{2}$ & $\mathrm{CaO}$ & $\mathrm{Fe}_{2} \mathrm{O}_{3}$ & $\mathrm{TiO}_{2}$ & $\mathrm{~K}_{2} \mathrm{O}$ & $\mathrm{Al}_{2} \mathrm{O}_{3}$ \\
\hline 1 & 0.024 & -0.019 & 0.212 & 0.096 & 0.275 & -0.010 \\
2 & 0.272 & 0.448 & 0.258 & 0.239 & 0.109 & -0.080 \\
3 & 0.500 & - & 0.526 & 0.300 & 0.486 & 0.133 \\
\hline
\end{tabular}

Note: XRF values are paired with the closest log value as a function of depth. Interval 1, $\mathrm{n}=103$; Interval 2, $\mathrm{n}=58$; Interval $3, \mathrm{n}=143$. 

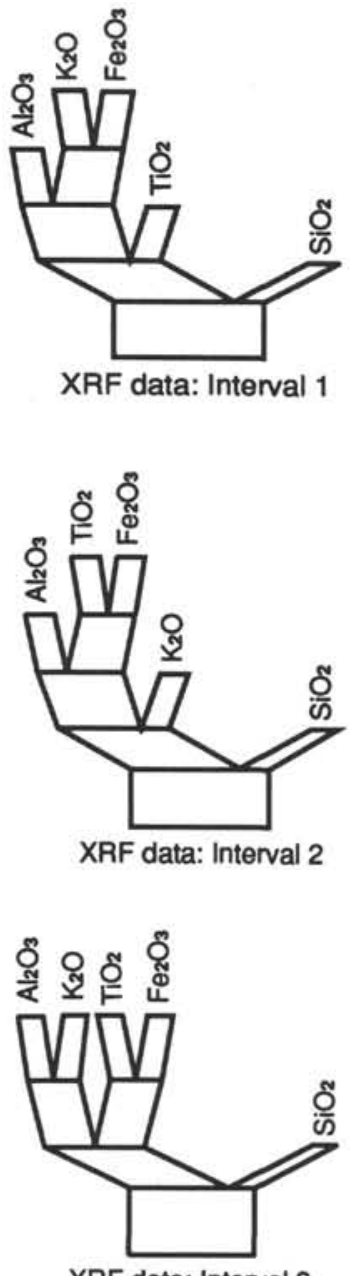

XRF data: Interval 3
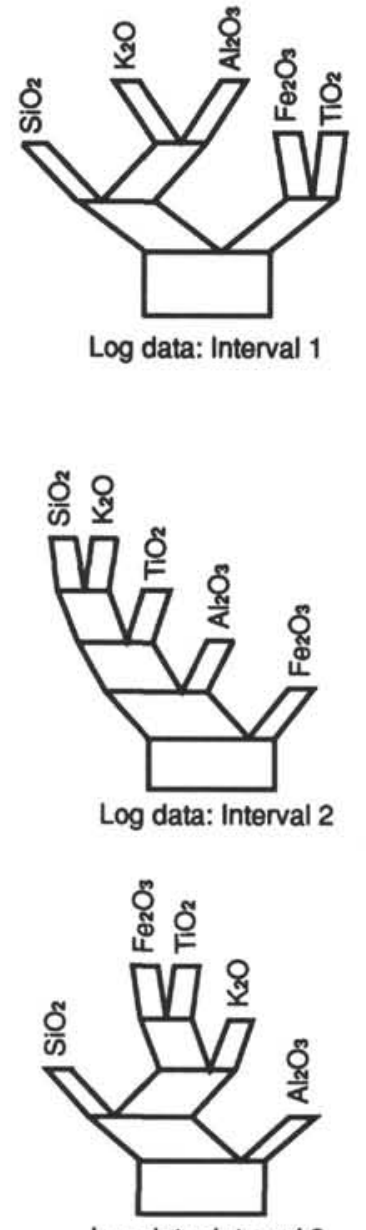

Log data: Interval 3

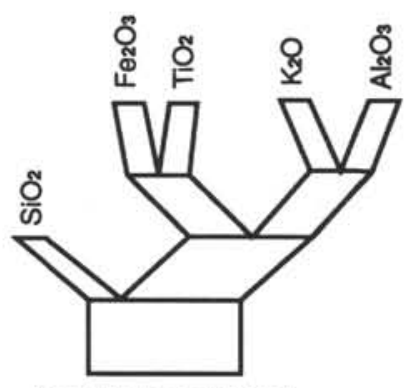

log data: whole well

Figure 3. Kleiner-Hartigan diagrams (Kleiner and Hartigan, 1981) for the core $\mathrm{XRF}$ and geochemical log-derived oxide data for the three sampled intervals and for the whole openhole logged section of Hole 798B (85-503 mbsf). The product moment correlation matrices are shown in Table 5.

malization factors (Fig. 7). For example, $\mathrm{SiO}_{2}$ for Interval 3 exhibits two fairly large discrepancies with observed core values at 263 and 270 mbsf (Fig. 6) that correlate with high normalization factors and associated statistical errors (Figs. 7 and 8). For comparison, in a typical industry well, the normalization factor ranges between 150 and 300 for the whole well, giving a statistical uncertainty for the derived elements approximately four times less than those for Hole 798B. Statistical uncertainties of the non-GST elements $\mathrm{Al}$ and $\mathrm{K}$ cannot be derived in the same manner.

\section{DISCUSSION}

The ability of the GLT to determine changes in formation geochemistry based on comparison with XRF analyses is clearly less than that determined by a similar study in another ODP environment (Jarrard and Lyle, 1991). The environment in which the GLT is examined for this study was more severe, more highly porous, and approached the limit at which geochemistry can be obtained within reasonable statistical bounds, based on uncertainty calculations from Grau et al. (1990).

The geochemical logs were processed in a way to maximize the resolution of the logs by keeping smoothing of the data to a minimum. This processing was performed before receiving the core XRF analyses. The Al log in particular shows an unexpectedly poor correlation with core data, compared to previous studies, where it has been one of the most accurately determined elements (e.g., Chapman et al., 1987). The post-cruise Al processing (Bristow et al., this volume) involves the combination of the raw NGT and AACT window count rates. In an attempt to gain maximum vertical resolution, the degree of smoothing of this input data to reduce random noise was insufficient, which resulted in the noisy appearance of this $\log$. Subsequent reprocessing of this $\log$ and the GST logs, with the availability of the core XRF data, should improve core-log correlation.

Some preliminary neutron modeling of this type of high porosity environment, performed using Schlumberger algorithms, suggests that the AACT in particular is adversely affected in these conditions. The AACT, with its lower energy source of neutrons, has a smaller and shallower depth of investigation than the GST. In the sampled intervals in Hole 798B, the average porosity is $75 \%$ and with a noneccentralized tool, the depth of investigation was calculated as less than $4 \mathrm{~cm}$. This shallow depth of investigation places a large statistical uncertainty on the measurement and is probably the primary cause for the poor nature of the derived $\mathrm{Al}$ data with respect to the other GLT-derived elements.

\section{CONCLUSIONS}

The weight percent oxides of $\mathrm{SiO}_{2}, \mathrm{Al}_{2} \mathrm{O}_{3} \mathrm{Fe}_{2} \mathrm{O}_{3}, \mathrm{~K}_{2} \mathrm{O}, \mathrm{TiO}_{2}, \mathrm{CaO}$ (determined from the GLT) have been compared with XRF results from core samples. The arithmetic means of the normalized XRFand log-derived oxides show good overall agreement. The correlation of the log oxide values with the XRF values is shown to be generally fair, but nonetheless variable. The very high porosity environment in the compared intervals hindered the ability of the GLT to determine the rock-forming oxides. The vast majority of the core measurements, however, fall within the bounds of statistical error predicted from the geochemical processing procedure.

Better correlation of the GST-derived $\mathrm{Cl} \log$ with formation porosity indicates that the recently introduced boron sleeve helps reduce the number of gamma-ray counts from the $\mathrm{H}$ and $\mathrm{Cl}$ content of the borehole fluid, and from Fe present in the tool itself. This is supported by an apparent increase in the accuracy of the Fe log, relative to the accuracy of the other GST-derived elements.

\section{ACKNOWLEDGMENTS}

We thank the shipboard scientific and technical parties; ODP for providing the samples; O. Don Hermes at the University of Rhode Island for the XRF analyses; Roger Anderson and the Borehole Research Group at Lamont-Doherty Geological Observatory for the use of their computing facilities and helpful discussions; and Jennifer Mahon-Tivy for editorial help. This research was supported by U.S. Science Advisory Committee grant TAMRF-20429. JFB thanks the Natural Environment Research Council (U.K.) for financial support. 

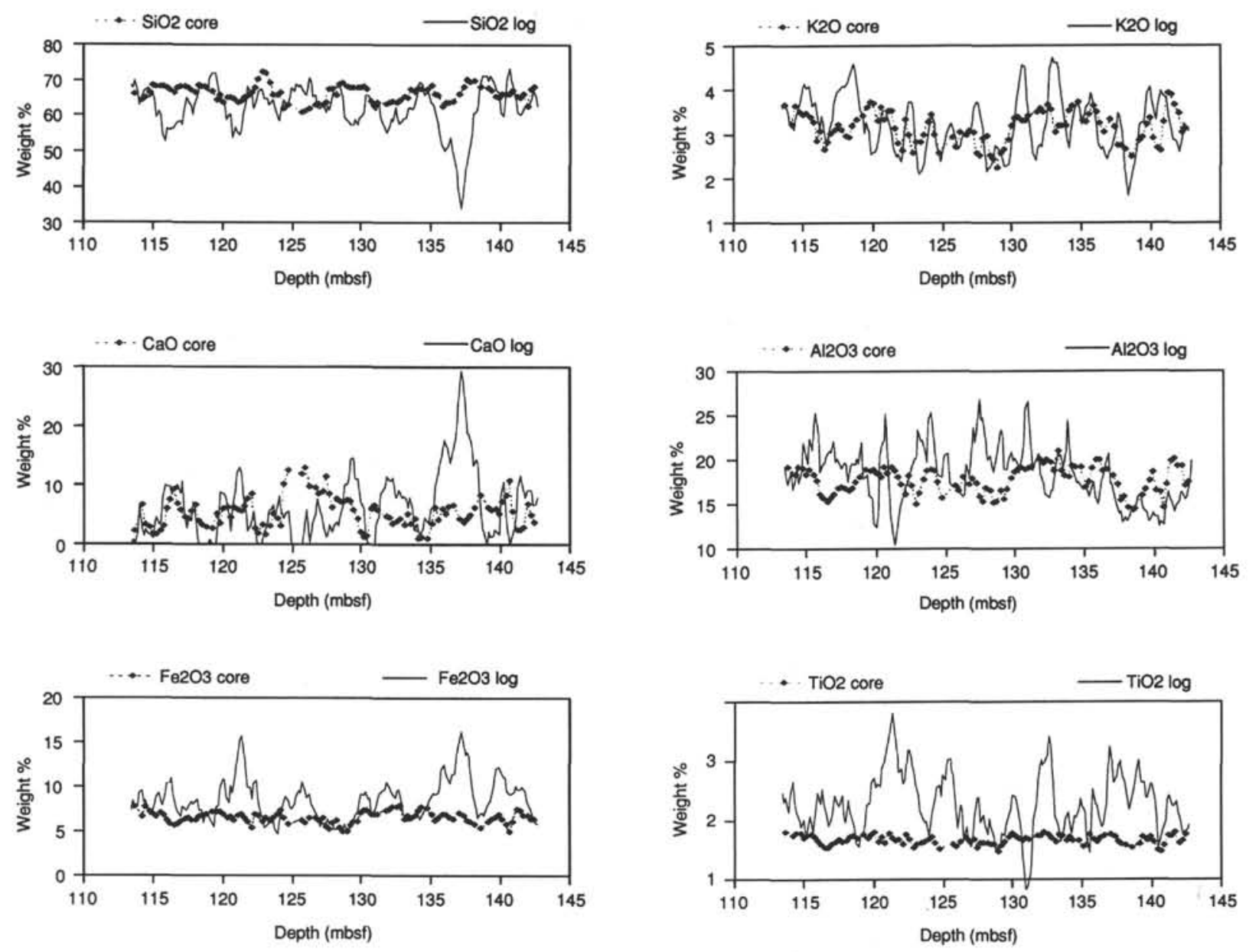

Figure 4. Core XRF and geochemical log-derived oxides plotted as a function of depth for sampled Interval 1 (Cores $13 \mathrm{H}$ through $15 \mathrm{H}$ ). Both data sets have the same scales, core XRF-determined depth from correlation shown in Figure 1. Log and XRF data have been normalized for the elements shown.

\section{REFERENCES}

Anderson, R.N., Dove, R.E., and Pratson, E., 1990. Geochemical well logs: calibration and lithostratigraphy in basaltic, granitic and metamorphic rocks. In Hurst, A., Lovell, M. A., and Morton, A. C. (Eds.), Geological Applications of Wireline Logs. Geol. Soc. Spec. Publ. London, 48:177-194.

Chapman, S., Colson, J.L., Flaum, C., Hertzog, R.C., Pirie, G., Scott, H., Everett, B., Herron, M.M., Schweitzer, J.S., La Vigne, J., Querein, J., and Wendlandt, R., 1987. The emergence of geochemical well logging. Tech. Rev., 35:27-35.

Dove, R.E., and Williams, C., 1989. Thermal conductivity estimated from elemental concentrations. Trans. Int. Spectroscopy Geochem. Symp., Ridgefield, CT.

Grau, J.A., Schweitzer, J.S., and Hertzog, R.C., 1990. Statistical uncertainties of elemental concentrations extracted from neutron-induced gamma-ray measurements. IEEE Trans. Nucl. Sci., 37:2175-2178.

Harvey, P.K., Bristow, J.F., and Lovell, M.A., 1990. Mineral transforms and downhole geochemical measurements. Sci. Drill., 1:163-176.

Herron, M.M., 1986. Mineralogy from geochemical well logging. Clays Clay Miner, 34:204-213.

Hertzog, R., 1979. Laboratory and field evaluation of inelastic neutron-scattering and capture gamma ray spectroscopy tool. Soc. Pet. Eng., AIME, Pap. 7430.
Hertzog, R., Colson, L., Seeman, B., O'Brien, M., Scott, H., McKeon, D., Grau, J., Ellis, D., Schweitzer, J., and Herron, M., 1989. Geochemical logging with spectrometry tools. SPE Formation Eval., 4:153-162.

Jarrard, R.D., and Lyle, M., 1991. High-resolution geochemical variations at ODP Sites 723, 728 and 731: a comparison of X-ray fluorescence and geochemical Logs. In Prell, W. L., Niitsuma, N., et al., Proc. ODP, Sci. Results, 117: College Station, TX (Ocean Drilling Program), 473-498.

Kleiner, B., and Hartigan, J.A., 1981. Representation of populations in many dimensions by trees and castles. J. Am. Statist., 76:260-269.

Lock, G.A., and Hoyer, W.A., 1971. Natural gamma-ray spectral logging. Log Analyst, 12:3-9.

Scott, H.D., and Smith, MP., 1973. The aluminum activation log. Log Analyst, $14: 3-12$.

Shipboard Scientific Party, 1990. Site 798. In Ingle, J.C., Jr., Suyehiro, K., von Breymann, M.T., et al., Proc. ODP, Init. Repts., 128: College Station, TX (Ocean Drilling Program), 121-236.

Wendlandt, R.F., and Bhuyan, K., 1988. Estimation of lithology and mineralogy from geochemical logging measurements. Trans. Int. Spectroscopy Geochem. Symp., Ridgefield, CT.

Date of initial receipt: 8 April 1991

Date of acceptance: 29 June 1992

Ms 127/128B-221 

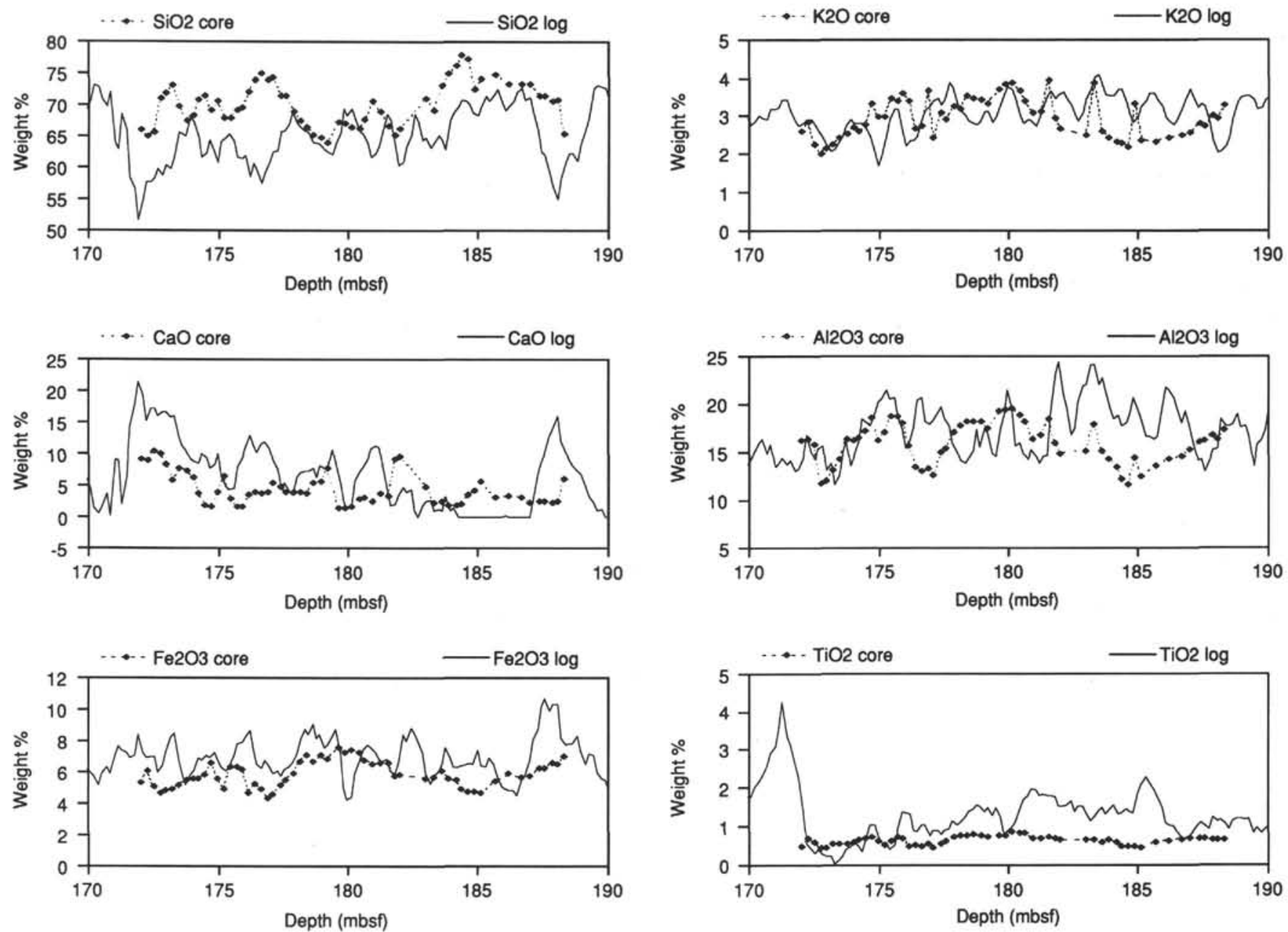

Figure 5. Core XRF and geochemical log-derived oxides plotted as a function of depth for sampled Interval 2 (Cores 19X through 20X). Both data sets have the same scales, core XRF-determined depth from correlation shown in Figure 1. Log and XRF data have been normalized for the elements shown. 

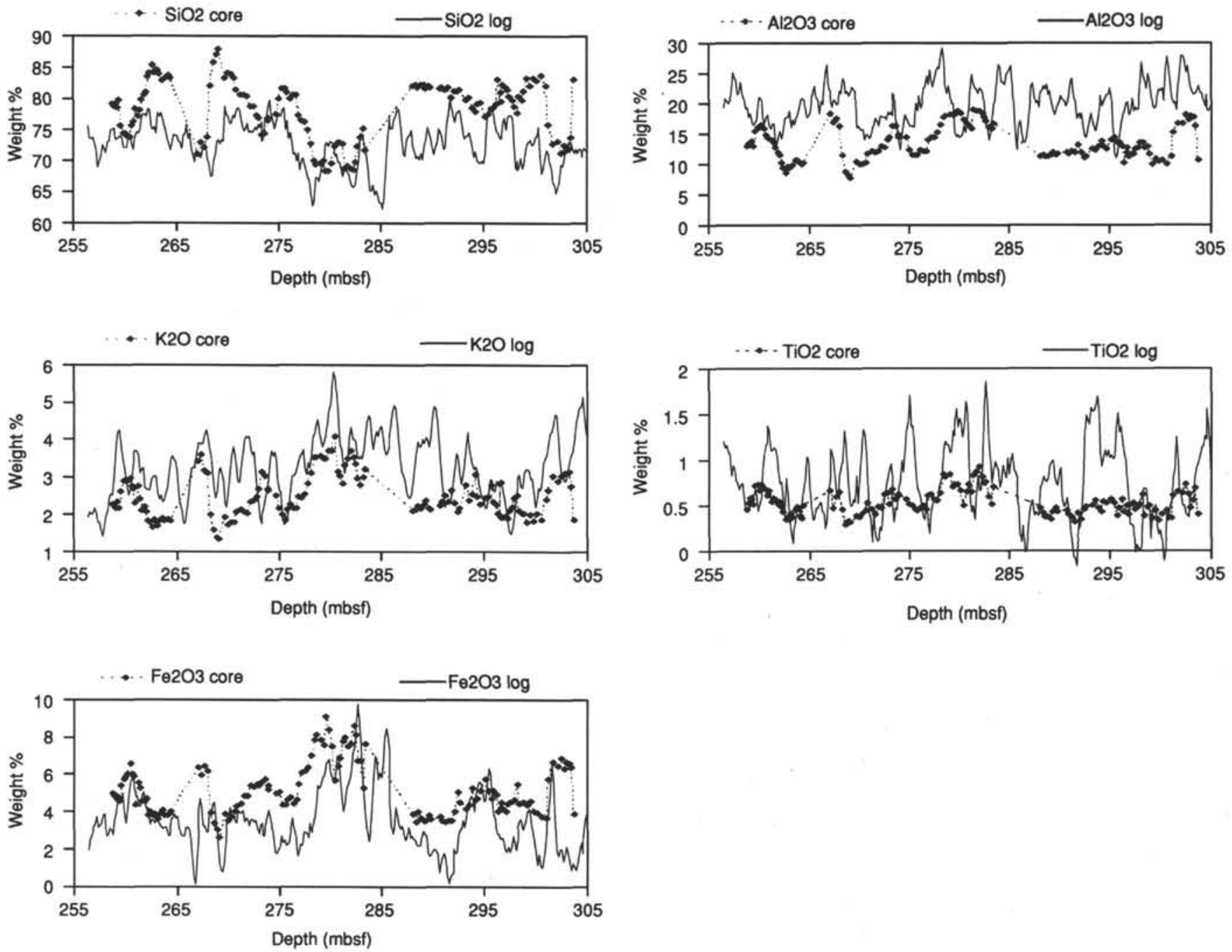

Figure 6. Core XRF and geochemical log-derived oxides plotted as a function of depth for sampled Interval 3 (Cores $28 \mathrm{X}$ through $32 \mathrm{X}$ ). Both data sets have the same scales, core XRF-determined depth from correlation shown in Figure 1. Log and XRF data have been normalized for the elements shown. 
Interval 1

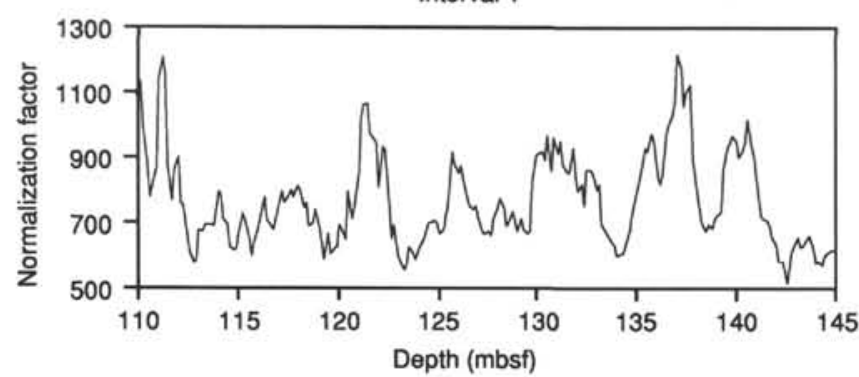

Interval 2

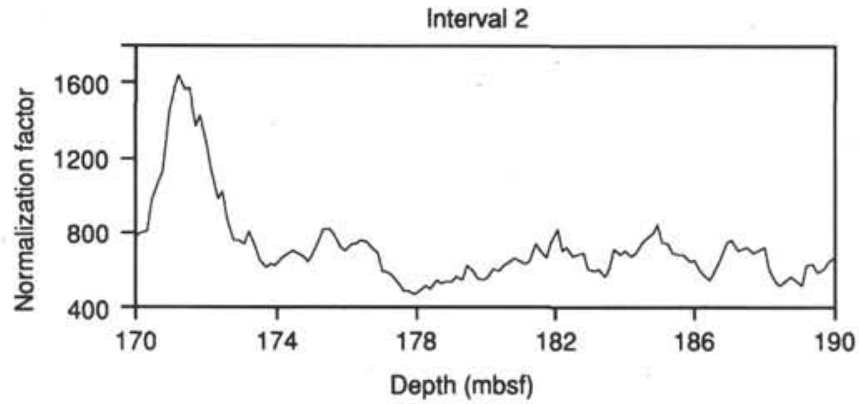

Interval 3

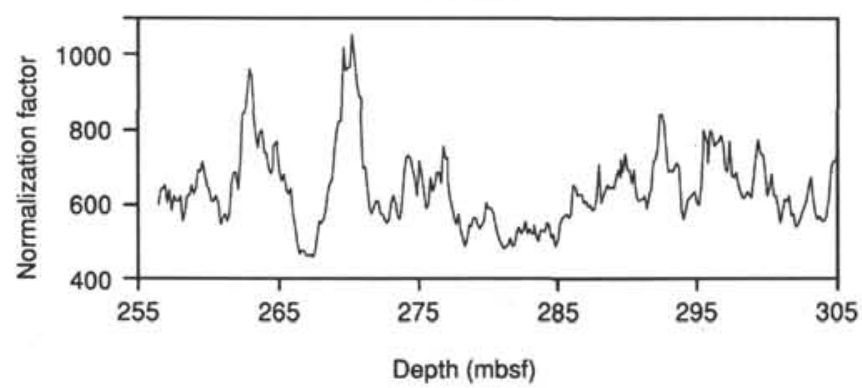

Figure 7. Normalization factor derived from the oxide closure model for the geochemical log data plotted as a function of depth for the three sampled intervals. The factor is derived at each depth interval to convert the relative elemental yields into weight percent elements. It has been calculated as a summation of, (elemental yields $\times$ oxide calibration factors)/spectral sensitivity coefficients. In zones where porosity is high and the captured gamma-ray signal from the matrix elements is poor, the normalization factor is high.
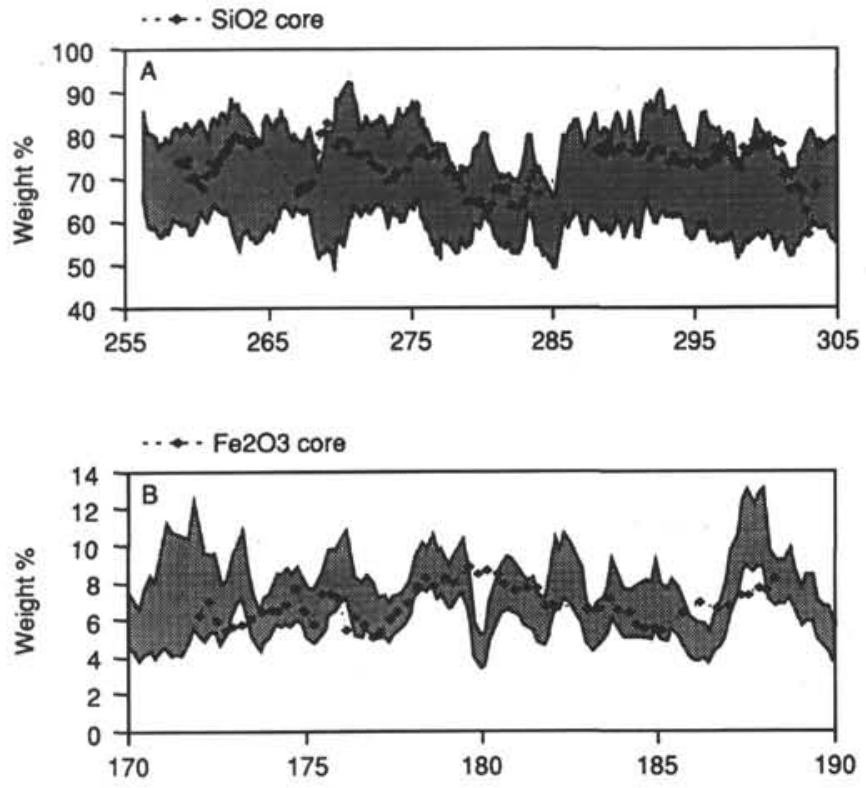

Figure 8. Core XRF values plotted as a function of depth with the shaded area representing the statistical uncertainty associated with the processing of the GST data (Grau et al., 1990). The two examples shown are $\mathrm{SiO}_{2}$ from sampled Interval 3 (A) and $\mathrm{Fe}_{2} \mathrm{O}_{3}$ from sampled Interval 2 (B). The plots show that the vast majority of the core XRF data fall within the statistical uncertainty of the GST data. 


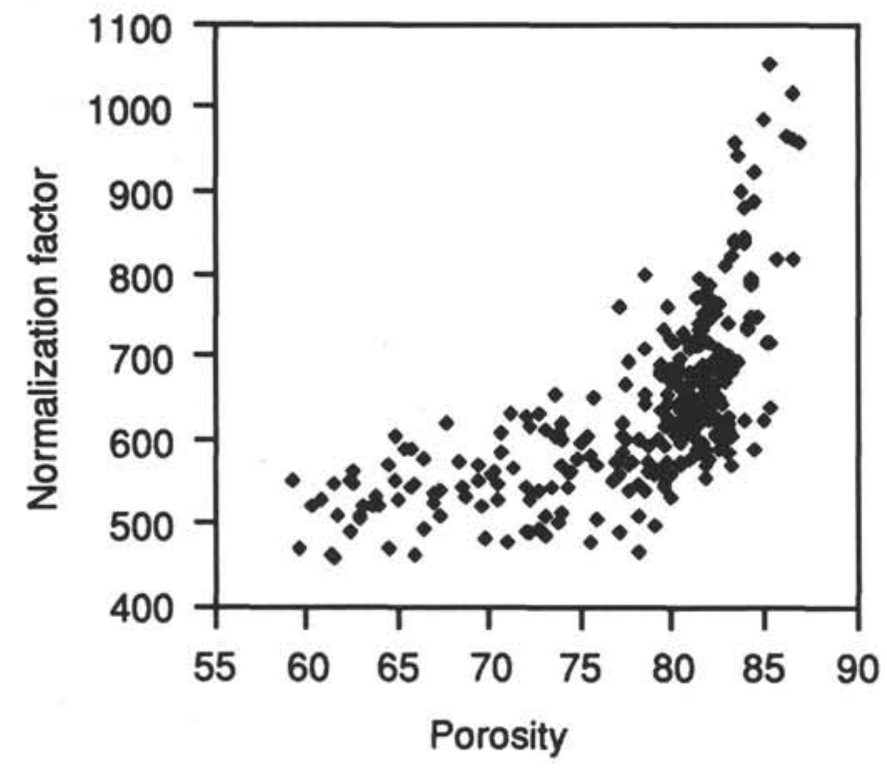

Figure 9. Normalization factor plotted vs. porosity showing an exponential increase of the normalization factor with higher porosity values.

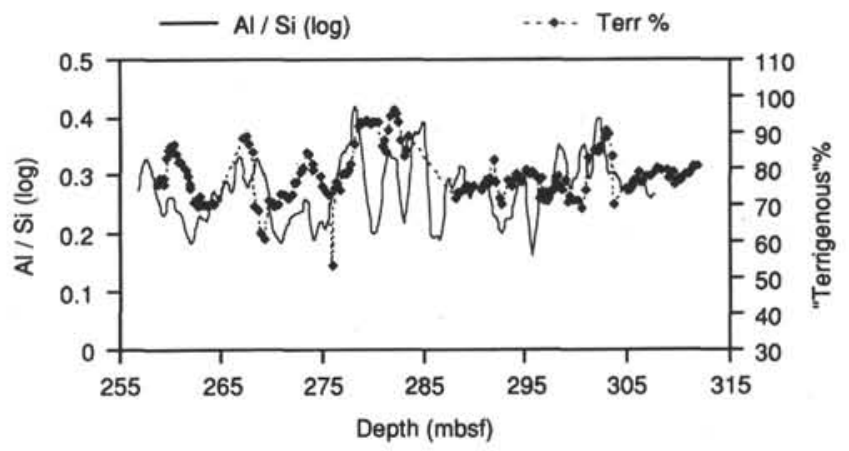

Figure 10. $\mathrm{Al}_{2} \mathrm{O}_{3} / \mathrm{SiO}_{2}$ ratio plotted with "terrigenous" percent as a function of depth for sampled Interval 3 (Cores $28 \mathrm{X}$ through $32 \mathrm{X}$ ). The correlation between the two indicate that the log-derived $\mathrm{Al}_{2} \mathrm{O}_{3} / \mathrm{SiO}_{2}$ ratio is a reasonable proxy for terrigenous percent. 